\title{
Haberde Objektiflik Tartışmaları: 31 Mart 2019 Yerel Seçimleri Örne ği
}

\author{
Emre Osman OLKUN* \\ Hamide SARITAŞ** (1)
}

ÖZ

Toplumların yaşamlarının bir parçası olan haber, yaşanan olaylara ilişkin bilgileri aktaran, bunları raporlayan niteliğe sahip içeriklerdir. Bu içeriklerin haber olarak nitelendirilmesi için sahip olması gereken bazı ilkeler bulunmaktadır. Bunlar; doğruluk, gerçeklik, objektiflik/nesnellik, anlamllık, kesinlik, hızlılık, tutarlılık ve inanılırlık olarak bilinmektedir. Bu çalışmada, haberin barındırması gereken unsurlardan objektiflik ilkesi üzerinde durulmuştur. Evrenini Türkiye'de bulunan siyasi partiler ve Türk yazılı basınının oluşturduğu bu çalışmanın, örneklemini ise Hürriyet, Sabah ve Sözcü gazeteleri oluşturmaktadır. 31 Mart 2019 Yerel Seçimleri öncesi yazılı basında objektiflik ilkesinin dikkate alınıp alınmadığı Sabah, Hürriyet ve Sözcü gazetelerinin seçime katılan partilere ve ittifaklara yönelik yayınladıkları haberlerin analizleri ile ortaya konulmaya çalışılmıştır. Analiz sonuçlarına bakıldığında, gazetelerin seçim haberlerinde partiye yaklaşımlarının daha çok nötr olsa da haberlerin anlatım tarzının ve üslubunun çoğunlukla eleştirel, suçlayıcı nitelikte olduğu ve haberlerde yorum yapıldığı görülmüştür. Bu durumda gazetelerin haber sunumlarında, objektif haberciliğin barındırması gereken denge, yorumsuz habercilik ve eşit alan/eşit zaman unsurlarının genel olarak göz ardı ettiği söylenebilir.

Anahtar Kelimeler: Haber, Objektiflik, İçerik Analizi, Gazeteler, Seçimler

\section{Objectivity Debates in the News: Example of 31 March 2019 Local Elections}

\begin{abstract}
News, which is a part of people's lives, is content that transfers information about the events that have occurred and reports them. In order for this content to be qualified as news, there are some principles that it have to have. These principles are known as truth, reality, objectivity, significance, certainty, promptness, consistency and believability. In this study, the principle of objectivity was emphasized. The sample of this work, which is composed of political parties in Turkey and the Turkish written press, is composed of the newspapers Hurriyet, Sabah and Sözcü. It was tried to reveal whether the principle of objectivity was taken into account in the printed media before the 31 March 2019 Local Elections, through the analysis of the news of Sabah, Hürriyet and Sözcü newspapers regarding the parties and alliances participating in the election. According to the results of the analysis, although newspapers ' approaches to the party were largely neutral in Election News, the style and style of reporting of the news were more critical, accusatory and commented on the news. In this case, it can be said that in the news presentations of newspapers, the balance, non-comment reporting and equal space/equal time elements that objective journalism should contain are generally ignored.
\end{abstract}

Keywords: News, Objectivity, Content Analysis, Newspapers, Elections

\section{Giriş}

Gazeteler yüzylllardır okuyuculara bulundukları çevre ve yaşadıkları dünya hakkında gelişmeleri aktaran içerikler sunmaktadırlar. Önceleri daha çok ticari olan bu içerikler zamanla ve değişen koşullara göre yine ekonomi başta olmak üzere siyasal, toplumsal ve kültürel gelişmeleri de aktarmışlardır. Gazetelerin yerine getirdiği bu işlev okuyucuları bilgilendirme, haberdar etme ve fikir edinmelerini sağlama olarak değerlendirilmektedir. Bu değerlendirmeden de anlaşllacağı üzere gazetelerin birincil işlevinin bilgilendirme olduğu bilinmektedir. Bilgilendirme işlevini gazeteler haberler ile gerçekleştirmektedirler. Haber yaşanılan çevrede gerçekleşen önemli olayların verildiği medya içerikleri olarak tanımlanmaktadır.

Gazeteciliğin ya da haberciliğin gelişmesi ve akademik alanlarda eğitimin verilmesiyle birlikte neyin haber olup neyin haber olamayacağı ya da gerçekleşen olayın önem derecesinin nasıl belirleneceği gibi tartısmalar başlatılmıştır. Bunların yanında ekonomik ve siyasal baskıların da yaşanmasıyla bu durum daha farklı boyutlara taşınmış ve artık objektif habercilik tartışmaları ortaya çıkmıştır. Gazetelerin siyasal yakınlık

\footnotetext{
* Dr. Öğr. Üyesi, Selçuk Üniversitesi, emreolkun@selcuk.edu.tr

**100/2000 YÖK Doktora Bursiyeri, hsaritas32@gmail.com

Makalenin Gönderim Tarihi: 29.03.2021; Makalenin Kabul Tarihi: 25.04.2021
} 
ya da baskılara ve ekonomik kazanımlara yönelik habercilik yaptığı yönünde gelişmelerin ortaya çıkması objektiflik tartışmalarını daha da görünür kılmıştır.

Haberde objektiflik tartşsmaları ve çalşsmalarının özellikle ülkelerin seçim dönemleri ve süreçlerine odaklanılarak seçim kampanyalarına ilişkin gazete haberleri, televizyon haberleri ve seçim fotoğrafları gibi medya içerikleri üzerine yapılmaktadır. Bunun nedeni medyanın yasama, yürütme ve yargıdan sonra dördüncü güç olarak görülmesinin ardında yatan gözetleme, denetleme ve düşünce pazarı oluşturma işlevini öncelikle siyasal boyutta yerine getirebileceğinin düşünülmesi gösterilmektedir (Özer, 2010, s. 108)

Alan yazında üzerinde özellikle belli dönemlerde üzerinde durulan haberde objektiflik çalışmalarına yeni ve güncel bilgiler eklemek üzere gerçekleştirilen bu çalışmanın amacını; 31 Mart 2019 Yerel Seçimleri öncesi Türk yazılı basınının (Sabah, Hürriyet ve Sözcü), seçime katılan partiler ve ittifaklara yönelik yapmış olduğu haberlerde objektif ilkesine riayet edip etmediklerini tespit etmek oluşturmaktadır. Bu amaç doğrultusunda yayın politikaları referans alınarak örnekleme dahil edilen Sabah, Hürriyet ve Sözcü gazetelerin ilk sayfalarında AK Parti, CHP, MHP, IYİ Parti, HDP, Saadet Partisi, Cumhur İttifak1 (AK Parti-MHP) ve Millet İttifakı (CHP-IYİ Parti) haberlerini ele alış biçimleri incelenmiştir. Çalışma daha önce yapılan çalışmalarla benzerlik ve farklılıkları ortaya çıkarma ve gelecekte yapılacak çalışmalara 1şık tutması açısından önem taşımaktadır.

\section{Kavramsal Çerçeve}

\subsection{Haber ve Objektiflik}

Haberler, bilgileri ileten ve olayların raporu niteliğinde içeriklerdir. Haber için kişinin yaşadığı hayattaki yerini belirleyip düzenlemesinde ve hayatına yön vermesinde duyduğu bilgi gereksinimlerinin karşılanmasıdır denilebilir. Söz konusu bilgiler ise kişilere ihtiyaçları, istekleri dahilinde veya dışında aktarılmaktadır. Her durumda haber kişilerin yaşamının bir parçasıdır ve yaşamlarında haberin önemli bir etkisi bulunmaktadır (Arsan \& Çoban, 2014, s. 44). Bir diğer tanıma göre haber, kamuoyunu ilgilendiren güncellik taşıyan, belirli bir olay ya da duruma ait bilgi niteliği taşıyan bir olayın aktarımıdır (Aslan, 2003, s. 16). Haberler, hammaddesi bir fikre, olaya ve soruna dayanan toplumsal içeriklerdir (Tokgöz, 2017, s. 256).

Doğumlar ve ölümler, afetler, felaketler, çatışmalar, benzerlikler, yakınlıklar, başarısızlıklar, üstünlükler ve benzer şekilde hayatın içinde insanla birlikte varlığını sürdüren birçok etmen, haberler için birer kaynak niteliği taşımaktadır. Dünya üzerinde insanın var olduğu her alanda, haber değeri taşıyan olay da mutlaka var olmaktadır (Girgin, 2000, s. 88).

Haber kavramına yönelik çeşitli tanımlamalar bulunmaktadır. Bunun nedeni olarak her bir haber tanımında farklı farklı unsurlara vurgu yapılması gösterilmektedir. Örneğin, yapılan tanımlamalarda zaman, gazeteci, hedef kitle ve sonuç gibi niteliklere vurgu yapıldığı görülmektedir. Böyle bir durumda üzerinde anlaşılmış tek bir haber tanımı yapmak oldukça zor görünmektedir (Aslan, 2003, s. 15). Haber ayrıca zamana göre de evrimleşebilmektedir. Kitle iletşşim araçlarında yaşanan gelişmeler ve akabindeki yenilikler haberin biçimine etki edebilmekte, bu da haberin tanımına yeni eklemeler yapılmasını sağlamaktadır.

Haber kavramını tanımlamada netlik sağlanamamış olsa da haberin içinde barındırması gereken nitelikler üzerinde anlaşma sağlanmıştır. Bu nitelikler; doğruluk, gerçeklik, nesnellik, anlamlılık, kesinlik, hızlılık, tutarllık ve inanilıllık ilkeleri olarak bilinmektedir (Tokgöz, 2017, s.158). Bu ilkeler genel olarak haber oluşumunda temel taşlardır.

Haberde bulunması gereken nitelikler arasında nesnellik ilkesi haber değerlendirilmesinde en çok tartşılan ilke olarak karşımıza çıkmaktadır. Haberin nesnelliği; haberin tarafsızlığı, objektifliği ve yansızlığ1 olarak da nitelendirilmektedir (Yüksel, 2010, s. 107). Haberde objektiflik en yaygın anlamıyla, haberi yazan kişilerin habere konu olan olayı kendi yorumlarını katmadan, kendi bakış açılarının dışında tarafsız bir gözle olaya ilişkin izlenimlerini aktarmalarıdır (Şeker, 2004, s. 35). Yani haberde muhabirin değer yargilarına, bireysel değerlendirmelerine ve ön yargilara yer verilmemelidir (Erdoğan \& Alemdar, 1990, s. 57). Çünkü objektiflik ciddi ve güvenilir haberciliğin ayrılmaz bir parçasıdır (İnal, 1996, s. 17).

Haberin 19. yüzyllda meta değerinin artması, gazetecilikte haber verme yönünde değişiklik getirmiştir. En önemli yenilik ise, sübjektif haber verme yerine objektif haber verme ilkesinin benimsenmiş olmasıdır. Objektif haber vermenin temelinde ise haberin taraf tutmadan, dengeli bir şekilde verilmesi yatmaktadır (Tokgöz, 2017, s. 423-424). Benzer şekilde haberin objektifliği için haberin hakkaniyetli, dengeli, yansız 
verilmesinin yanında, haberde çarpıtma yapılmaması, doğru, ön yarg1sız ve yorumsuz verilmesi gerekmektedir (Özer, 2010, s. 108).

Haberde objektiflik unsurundan bahsedebilmek için var olan durum, olay ya da olgunun bir medya içeriği olarak hangi boyutta nasıl seçildiği, seçilen bu konunun yazımında ve yayınlanmasında nelere dikkat edildiğine bakılması gerekmektedir (Olkun, 2017, s. 99). Bu nedenle haberde objektifliği sağlamak için netlik, denge ve eşit alan/eşit zaman unsurlarına dikkat çekilmektedir (Yüksel, 2010, s. 108)

Objektifliğin sağlanması için; haberde kaynak gösterme anlamına gelen netlik ilkesi, haber kaynağının yanında haberi yapan muhabirin bilgilerinin de açık bir şekilde haberde verilmesini içermektedir (Yüksel, 2010, s. 109). Objektiflik unsurlarından denge ilkesi, haberde yer alan karşıt görüşlerin her birine yer verilmesi olarak tanımlanmaktadır. Burada gazeteciye önemli bir görev düşmektedir. Gazeteci tarafsızlığını koruyarak, bireysel görüşüne ve inancına uymasa da, söylenenlere ve topladığ1 bilgilere inanmasa da haberde adı geçen bütün kişilere söz hakkı tanıyarak denge unsurunu sağlamalıdır (Aslan, 2003, s. 134). Denge unsurunun sağlanamaması objektif habercilik açısından büyük bir sorun olmakla birlikte, haberin eksik olmasina da neden olacaktur.

Bir diğer objektiflik unsuru olan eşit alan/eşit zaman ilkesi denge unsuruyla ilişkili olarak haberde verilen farklı görüşlere dikkat çekilerek, bunların eşit oranda haber içeriğinde yer verilmesini sağlamaktır (Yüksel, 2010, s. 109-110). Basılı medya içeriklerinde, verilen duruma ilişkin karşıt görüşlerin eşit sütun veya satır ayırarak yapılması şeklinde açıklanabilen bu unsur, görsel veya işitsel medya içeriklerinde eşit zaman ayırarak yapilması anlamına gelmektedir (Olkun, 2017, s. 106).

Haber içeriklerinde objektifliği sağlamada bahsedilen bu ilkeler teorik olarak varllğını korusa da uygulama da bunlara uyulması oldukça zor olmaktadır. Haber ve objektiflik üzerine yapılan araştırmaların yöntemlerinde farklılıklar bulunsa $\mathrm{da}$, bu çalışmalarda haberlerde taraflara ayrılan yer ve zaman eşitsizliklerine, içerikte yer alan bilgilere yönelik olumlu, olumsuz yorumda bulunma ya da nötr kalma gibi değerlendirmeler yapıldığ1 görülmüştür (Hackett, 2000, s. 35).

\subsection{Haberde Objektiflik Tartışmaları}

Objektif habercilik üzerine çok sayıda eleştiri bulunmaktadır. Bazı araştırmacılara göre 21. yüzyıl haber tüketicilerinin objektif yayıncılık düşüncesi, yalnızca bir düşünceden ibaret olduğunun ve gazetecilik pratiğinde tümüyle başarılamayacağını dile getirmişlerdir (Hackett, 2000, s. 38-46; Harrison, 2000: 147-149; McNair, 2005).

Haberde objektiflik tartşmalarında daha çok insan faktörü nedeniyle haberde objektifliğin sağlanamayacağı savunulmaktadır. Bunun yanında kişisel özellikler, ideolojik farklılıklar, değer yargıları gibi birçok değişken de haberin objektifliği noktasında tartşılmaktadır. Ancak haberde objektifliğin sağlanamaması noktasında özellikle tartışılan unsurlar, medyanın yapısal yanlılığı ve sahiplik unsuru olarak karşımıza çıkmaktadır (Yüksel, 2010, s. 107). Özellikle günümüzde medya kuruluşlarının siyasal ve ekonomik çıkarlanı doğrultusunda haber yapmaları yansız, dengeli ve objektif habercilik olasıllğını ortadan kaldırmaktadır (Hackett, 2000, s. 60). Çünkü bu kuruluşların elde edeceği ekonomik kar ve siyasal olarak belli bir noktada olduklarını ortaya koyma çabaları, habere haber olma niteliği kazandıran objektiflik unsurunu ihlal etmelerine neden olmaktadir.

Haberde objektiflik tartışmaları içerisinde dikkat çeken bir diğer nokta basın meslek ilkeleri içinde objektiflik sözcüğüne çok fazla yer verilmemesidir. Bunun sebebinin gazetecilerin yapmış oldukları haberlerde objektif olamayacakları inancıdır (İrvan, 2004, s. 7). Çünkü haberde objektiflik sağlanması noktasında ilk akla gelen haberi yazan muhabirin haberinde kendi gözlem, düşünce veya yorumuna yer vermemesi olarak gösterilmektedir (Özer, 2012, s. 246). Bu görüşe benzer olarak medya mensuplanının da, toplumun diğer bireyleri gibi içine doğdukları ve yaşamlarını sürdürdükleri sosyal, siyasal ve ekonomik ortamın ürünü olduklarını, bu nedenle bu ortamdan etkilenerek geliştikleri vurgulanmaktadır. Sonuç olarak, medya kuruluşu sahiplerinden çalısanlarına kadar herkesin bir dünya görüşü bulunmaktadır. Bu nedenle bu kişilerin toplumsal yapısı ve düşüncesi tarafsız olmamaktadır (Girgin, 2003, s. 96).

Öyle ki haberde objektifliğin mümkün olmayacağı düşüncesinin yaygınlaşmasıyla gazeteciler ve gazetecilik üzerine çalışanlar son yıllarda, objektiflik kavramı yerine dürüstlük kavramını özellikle 
kullanılmaya başlanmıştır (Bennett, 2000, s. 280-281). Çünkü genel olarak, habercilerin içinde yaşadıklanı ve anlamlandırdıkları toplum ve değerler, haber içeriklerine yansıyacaktır görüşü hâkim olmaktadır.

\subsection{Türkiye'de Haberde Objektiflik Üzerine Yapılmış Çalışmalar}

Türkiye'de iletişim alanında haber ve habercilik üzerine çeşitli araştırmacıların, konuyu ele alış ve örneklem seçimi açısından farklılık gösteren çok sayıda çalışması bulunmaktadır. Bu çalışmalardan birini Tülay Şeker'in "Türk Basınında Objektiflik Fazilet Partisi'nin Kapatılması Örneğì" adlı çalışması oluşturmaktadır. Şeker, bu çalışmasında gazetelerin ve gazetecilerin haberlerde verilen gelişmeleri ispatlama, yalanlama ya da savunma gibi davranışlarında bulunduklarını belirlemiştir. Böylece yazar gazetelerin ve gazetecilerin haberde objektiflik ilkesine uymadıklarını ortaya koymuştur (Şeker, 2004).

Bir diğer çalışma ise Özer'in objektif habercilik ideali açısından; dengelilik ve hakkaniyet unsurları ile nötr tutumu ortaya koymaya yönelik yapmış olduğu bir çalışmadır. Araştırmada 22 Temmuz 2007 Genel Seçimleri'nde Cumhuriyet ve Yeni Şafak gazetelerinin, CHP ve AK Parti'ye yönelik tutumları ele alınmıştır. Çalışma sonucuna göre her iki gazetenin de ilgili partilere yönelik yapmış olduklant haberlerde kısmen de olsa hakkaniyetli olmaya çalıştıkları ancak tarafsızlıklarını koruyamadıkları ve haber sunumlarında dengeli davranmadıkları saptanmıstır (Özer, 2010: 173).

Konuyla ilgili bir diğer çalışma, Diler’in içerik analizi ve söylem analizi yöntemlerini birlikte kullandığı, "Televizyon Haberlerinde Tarafsızlık ve Nesnellik: Eleştirel Bir Yaklaşım” isimli uzmanlık tezinde 'Televizyon haberleri, kitle iletişim araçlarının yapısal yanlllığından ötürü nesnel değildir.' hipotezini sınamak için NTV, ATV, Show TV, Kanal D ve STV kanallarını örneklem olarak almıştır. Araştırmada elde ettiği bulgularla, televizyon haberlerinin nesnel ve tarafsız olmadıkları sonucuna ulaşmıstır (Diler, 2011).

Kılıç'ın yerel basında objektifliğe yönelik tutumu araştırdığı “Antalya'daki Yerel Gazetelerin Siyasal Yanlılık Açısından İncelenmesi” çalışmasında Antalya'da bulunan 13 yerel gazetede belediyelere ilişkin haberleri ve köşe yazılarını incelemiştir. Yapılan araşturma sonucunda, incelenen gazetelerin bir kısmının iki farklı partiye ait belediyeler ile ilgili haber ve köşe yazılarında taraflı bir tutum izlediği, sözü edilen yanlılı̆̆n ise partizan nitelik taşıdığ1 sonucuna ulaşmıştır (Kılıç, 2011).

Konuyla ilişkili olarak Olkun'un içerik analizi yöntemi kullanarak yapmış olduğu "Cumhurbaşkanlı̆ğ Seçiminde Türk Yazılı Basınının Adaylara Yaklaşımı: Milliyet, Sabah ve Zaman Gazeteleri Örneği”" çalısmasında ise söz konusu gazetelerin ele almış oldukları haberlerde aday ya da partilere ilişkin olumlu ya da olumsuz yorum ve ön yargıda bulundukları, bazı adayları görmezden gelirken diğerlerini daha çok ön plana çıkararak objektifliğin önemli bir ilkesi olan denge unsuruna önem vermediklerini bulgulamışır (Olkun, 2015).

Akkaya'nın 2017 Referandumu sürecinde yazılı basının tutumunu içerik analizi yöntemi kullanarak incelediği, "Yazılı Basında Tarafsızlık İlkesi ve 2017 Referandumu" adlı çalışmasında, özellikle seçim ve referandum gibi süreçlerde bireylerin artan bilgi ihtiyaçlarına ilişkin gazetelerin doğru ve tarafsız bilgi aktarımının yerine, yanlı ve nesnellikten uzak, haberlerin daha çok gazetelerin benimsemiş olduğu ideolojik kimliklere göre şekillendiği sonucuna ulaşmıştır (Akkaya, 2019).

\section{31 Mart 2019 Yerel Seçimleri Öncesi Türkiye'de Siyasal Durum}

Siyasi seçimler, toplumların ve bu toplumda yaşanan dönemlerin koşullanı altında gerçekleşir. Dolayısıyla bu seçimler toplumda hâkim olan gelişmelerle ilişkili olarak şekillenirler (Miş \& Eren, 2014, s. 26). Bu nedenle, 31 Mart 2019 Yerel Seçimleri'ne Türkiye'de yaşanan; 15 Temmuz darbe girişimi, Firat Kalkanı Harekâtı, Cumhurbaşkanlığı sistemi referandumu, IYYI Parti’nin kuruluşu, Zeytin Dalı Harekâtı, Cumhur İttifakı ve Millet İttifakı oluşumları gibi başlıca gündem maddeleriyle gidilmiştir.

15 Temmuz 2016 tarihinde FETÖ darbe girişiminde bulunmuştur. Bu darbe girişimi sırasında Cumhurbaşkanı Recep Tayyip Erdoğan ile CNN Türk Ankara temsilcisi Hande Firat ile akıllı telefon aracilığılla görüntülü konuşma gerçekleştirmiş, bu konuşmada Cumhurbaşkanı Erdoğan, darbe girişimi karşısında halka meydanlara ve havaalanlarına çıkmaları için çağrıda bulunmuştur. Bu çağrı üzerine halk darbe girişimine karşı direniş için sokaklara ve meydanlara çıkmış, tankların önünde durmuşlardır. $\mathrm{Bu}$ 
darbe girişimine karşı Türk milletinin gösterdiği tepki dünya kamuoyunda oldukça dikkat çekmiştir (Devran \& Özcan, 2016, s. 82).

Bu başarısız darbe girişimi sonrasında, 7 Ağustos'da milli birlik ve beraberliğin bir göstergesi olarak düzenlenen Yenikapı Mitingi'nde MHP lideri Devlet Bahçeli'nin AK Parti ve Cumhurbaşkanı Recep Tayyip Erdoğan'nın yanında olduğunu belirtmesinin yanında (Bekiroğlu ve Balc1, 2019, s. 8), Bahçeli’nin Anayasa'nın yeniden yazımına olumlu baktı̆̆ını ifade etmesi ve 16 Nisan 2017 düzenlenecek referandumda da "evet" diyeceğini açıklaması AK Parti ile MHP'nin yakınlaşmasını görünür kılmıştır (Aslan, 2019, s. 12). Yaşanan bu gelişmeler, AK Parti ve MHP arasında oluşacak olan Cumhur İttifakı'nın işaretleri olarak yorumlanabilir.

24 Ağustos 2016 tarihinde Türk Ordusu ve desteklediği Özgür Suriye Ordusu (ÖSO), sinırın Suriye tarafindan terör örgütü DEAŞ’1 uzaklaştırmak amacıyla askeri bir operasyon başlatmıştır. Bu operasyonla belli bir bölge DEAŞ’ın elinden alınmıştır (Köker, 2016).

16 Nisan 2017'de başkanlık sistemi ya da Cumhurbaşkanlığı hükümet sistemi halk oylamasına sunulmuştur. 16 Nisan'da halkoyuna sunulan sistem değişikliğin, halkın çoğunluğunun (yüzde 51,41) onay vermesiyle Türkiye'de Cumhurbaşkanlığı hükümet sistemine geçilmiştir. Bunun yanında 2017 yllının son aylarında MHP lideri Bahçeli’nin seçim barajının ağır olduğu ve düşürülmesi gerektiğini ifade etmiş ve tavsiye olarak Cumhur İttifakı önerisinde bulunmuştur. Bunun üzerine 10 Ocak 2018'de Cumhurbaşkanı Erdoğan ile Bahçeli görüşerek ittifak konusunda anlaşmış ve iki parti arasında Cumhur İttifakı kurulmuştur (Bekiroğlu \& Balc1, 2019, s. 8).

7 Haziran 2015 Genel Seçimleri'nden sonra MHP içerisinde oluşan parti içi iktidar kavgalant, kurultay çatışmaları sonucunda 25 Ekim 2017 tarihinde Meral Akşener liderliğinde IYII Parti kurulmuştur. IYYI Parti, MHP içerisindeki muhalif ekibin parti genel başkanı ile anlaşmazlığa düşmesi sonucunda oluşmuştur. IYI Parti'nin kurulmasıly birlikte Türkiye'de var olan bir parti içinden çıkarak oluşan partilere bir yenisi daha eklenmiştir (Duran, 2017, s. 9).

Siyasal alanda tüm bu gelişmeler yaşanırken, Türkiye'nin ulusal güvenliğini korumaya yönelik, 21 Ocak 2018 tarihinde Türk Silahlı Kuvvetleri tarafından Suriye'nin Afrin bölgesindeki PKK/PYD/YPG ve DEAŞ hedeflerine yönelik "Zeytin Dalı Harekâtı" düzenlemiştir. Zeytin Dalı Harekâtı, Suriye'nin kuzeyinde ulusal güvenliğe yönelik tehdit oluşturan terör örgütlerinin etkisiz hale getirilmesi ve sinır güvenliğinin sağlanması için yapılmıștır (https:/ / www.internethaber.com).

AK Parti ve MHP'nin Cumhur İttifakı'na karşı, CHP ile yeni kurulan IYI Parti arasında ittifak şekilleri ve seçim güvenliği gibi konular kamuoyuna duyurulmadan görüşülmüştür. Bu süreçte yaşanan gelişmeler sonucunda 5 Mayls 2018 tarihinde CHP, IYI Parti, Saadet Partisi ve Demokrat Parti (DP) "Millet İttifakı'nı" kurma noktasında anlaşmışlardır (Bekiroğlu \& Balcı, 2019, s. 13). Böylece Cumhur İttifakı'na karşı Millet İttifakı kurulmuştur.

Türkiye'nin siyasal yaşamı ve geleceği için 24 Haziran 2019 tarihinde yapılan Cumhurbaşkanlığı seçimleri oldukça önemlidir. Bu seçim, daha önce oluşan ittifaklar, ittifakları oluşturan partiler ve cumhurbaşkanı adaylarının yarışması açısından önem taşımaktadır. Seçimde cumhurbaşkanı adayları; AK Parti ve MHP'nin Recep Tayyip Erdoğan, CHP'nin Muharrem İnce, IYİ Parti'nin Meral Akşener ve HDP'nin adayı ise Selahattin Demirtaş olmuştur (Çağlar vd., 2018: 9). Seçim sonucunda Recep Tayyip Erdoğan yüzde 52,59 oy oranıyla yeni sistemin ilk Cumhurbaşkanı olmuştur. AK Parti ve MHP'nin oluşturduğu Cumhur İttifakı yüzde 53,66 oranında oy alarak mecliste çoğunluğu elde etmiştir. CHP, IYİ Parti ve Saadet Partisi’nin oluşturduğu Millet İttifakı ise yüzde 33,94 oranında oy almıştır (Miş \& Duran, 2018, s. 9).

Türkiye tüm bu gelişmelerin bileşiminde 31 Mart 2019 Yerel Seçimleri için sandığa gitmiştir. Bu seçimde AK Parti ve MHP'nin oluşturduğu Cumhur İttifak1 yüzde 51,64 oranında oy alırken, CHP ve İYI Parti'nin oluşturduğu ve HDP'nin de desteklediği Millet İttifakı ise yüzde 37,57 oranında oy almışır (Miş \& Duran, 2019, s. 372-373).

\section{Yöntem}

Gazetelerin 31 Mart 2019 Yerel Seçimleri’ne katılan partilere olan yaklaşımının incelendiği bu çalışmada içerik analizi yöntemi kullanılmıştır. İçerik analizi yöntemi, medya içeriklerinde kullanılan, niceliksel, 
sistematik ve nesnel bir yöntemdir (Wimmer ve Dominick, 2007: 19: 21). Medya metinlerinde yer alan ve ifade edilenlere bakarak hazırlanan açıklayıcı bir kodlama cetveliyle, medya içeriklerinde ne sıklıkla ifade edildiği ya da yazıldığının ortaya konmasını sağladığ1 için içerik analizi yöntemi en uygun yöntem olarak seçilmiştir.

Bu çalışmanın amacı, 31 Mart 2019 Yerel Seçimleri sürecinde yazılı basının seçimlere katılan Ak Parti, MHP, CHP, IYİ Parti, HDP, Saadet Partisi ve bu partilerin oluşturduğu Cumhur İttifakı (Ak Parti-MHP) ve Millet İttifakı'na (CHP, IYİ Parti) yönelik haberlerinde nasıl, ne ölçüde ve ne sılklkla yaklaştığ1, bu yaklaşımlarda objektiflik ölçülerine uyulup uyulmadığını ortaya koymaktır.

Evrenini Türkiye'de bulunan siyasi partilerin ve Türk yazılı basınının oluşturduğu bu çalışmanın örneklemini ise Hürriyet, Sabah ve Sözcü gazeteleri oluşturmaktadır. Bu gazetelerin örneklem olarak seçiminde gazetelerin yayın politikaları ve ideolojileri dikkate alınmıştır. Bu bakımdan Hürriyet gazetesi merkezi temsilen, Sabah gazetesi hükümete yakınlığından, Sözcü gazetesi ise hükümete karşı sergilediği muhalif tutuma sahip olmasıyla örneklem olarak seçilmiştir.

Çalışma, seçimden önceki 4 haftalık dönemi yani 3 Mart 2019 ve 30 Mart 2019 tarihleri arasını kapsayacak şekilde, gazetelerin ilk sayfalarında partilerin seçime yönelik çıkan haberleri ve bu haberlerin devamı olan sayfalarla sınırlandırılmıştır. Analiz için gazetelerin ilk sayfalarının seçilmesinin nedeni; gazetelerin ilk sayfalarının en önemli sayfasını oluşturmasıdır.

\section{Bulgular ve Yorum}

31 Mart 2019 Yerel Seçimleri’ne kattlan partilere, yazılı basının yaklaşımı örneklem olarak seçilen üç gazetenin (Hürriyet, Sabah ve Sözcü Gazeteleri) 03 Mart 2019-30 Mart 2019 tarihleri arasında ilgili gazetelerin ilk sayfalannda çıan haberler ve bu haberlerin iç sayfalardaki devamı olan haberler içerik analizi yöntemiyle çözümlenmiştir. Çalışmada veri toplama aracı olarak 13 adet sınırlandırma sisteminden oluşan kodlama cetveli kullanılmıştır. Çalışmanın güvenilirliğini sağlamak için aynı veriler 2 farklı kodlayıcı tarafından kodlanmıs, elde edilen sonuçlar karşılaştırıldı̆̆ında 2 kodlayıcı arasında yüzde 95'in üzerinde bir uyum tespit edilmiştir. Kodlanan veriler SPSS 25 programı ile analiz edilmiş ve elde edilen verilerin analizinde frekans ve çapraz tablo analizi kullanılmıştır.

Tablo 1. Seçim Haberlerinin Yayınlandığ Gazeteler

\begin{tabular}{|c|c|c|c|}
\hline Gazeteler & Say1 & Yüzde & Toplamlı Yüzde \\
\hline Sözcü & 106 & 41,1 & 41,1 \\
\hline Sabah & 78 & 30,2 & 71,3 \\
\hline Hürriyet & 74 & 28,7 & 100,0 \\
\hline Toplam & $\mathbf{2 5 8}$ & $\mathbf{1 0 0 , 0}$ & \\
\hline
\end{tabular}

Analizlere göre, gazetelerin ilk sayfalarında 28 günlük sürede toplam 258 haberin yayınlandığı bulgulamıştır. Incelenen bu haberlerin 106’sı Sözcü Gazetesi'nde, 78'si Sabah Gazetesi'nde ve 74'ü ise Hürriyet Gazetesi'nde yayınlanmıştur. Sonuçlara bakıldı̆̆ında, seçimle ilgili birinci sayfalarında en fazla habere yer veren gazete Sözcü Gazetesi olmuştur.

Tablo 2. Seçim Haberlerinin Yayınlandığ1 Haftalar

\begin{tabular}{|c|c|c|c|}
\hline Haftalar & Say1 & Yüzde & Toplamlı Yüzde \\
\hline 03-09 Mart 2019 (Birinci Hafta) & 75 & 29,1 & 29,1 \\
\hline 10-16 Mart 2019 (İkinci Hafta) & 73 & 28,3 & 57,4 \\
\hline 17-23 Mart 2019 (Üçüncü Hafta) & 57 & 22,1 & 79,5 \\
\hline 24-30 Mart 2019 (Dördüncü Hafta) & 53 & 20,5 & 100,0 \\
\hline Toplam & $\mathbf{2 5 8}$ & $\mathbf{1 0 0 , 0}$ & \\
\hline
\end{tabular}

Seçim haberlerinin yayınlandı̆̆ı haftaların incelendiği tabloya bakıldığında, birinci hafta (03 - 09 Mart 2019) yüzde 29,1, ikinci hafta (10-16 Mart 2019) yüzde 28,3, üçüncü hafta (17-23 Mart 2019) yüzde 22,1, dördüncü hafta (24-30 Mart 2019) 20,5 oranında haber yayınlandığ1 görülmektedir. Bu sonuçlara bakıldığında seçim sürecinin ilk ve ikinci haftasında gazetelerde seçimle alakalı daha çok haber yayınlandığı görülmektedir. 
Tablo 3. Seçim Haberlerinin Gazete Sayfasındaki Konumu

\begin{tabular}{|c|c|c|c|}
\hline Haberin Konumu & Say1 & Yüzde & Toplamlı Yüzde \\
\hline Sayfanın muhtelif yerleri & 209 & 81,0 & 81,0 \\
\hline Manşet & 42 & 16,3 & 97,3 \\
\hline Sürmanşet & 7 & 2,7 & 100,0 \\
\hline Toplam & $\mathbf{2 5 8}$ & $\mathbf{1 0 0 , 0}$ & \\
\hline
\end{tabular}

31 Mart 2019 Yerel Seçimleri’nin konu edinildiği haberlerin gazete sayfasındaki konumuna bakıldı̆̆ında, seçim haberlerinin yüzde 81 'inin gazetenin ilk sayfasının muhtelif yerlerinde, yüzde 16,3'ünün manşetten, yüzde 2,7'sinin ise sürmanşetten verildiği tespit edilmiştir. Sonuçlara göre seçim haberleri çoğunlukla, gazetelerin birinci sayfalarının muhtelif yerlerinde verilmiştir.

Tablo 4. Seçim Haberlerine Konu Olan Partiler

\begin{tabular}{|c|c|c|c|}
\hline Partiler & Say1 & Yüzde & Toplamlı Yüzde \\
\hline Ak Parti & 110 & 42,6 & 42,6 \\
\hline CHP & 88 & 34,1 & 76,7 \\
\hline MHP & 26 & 10,1 & 86,8 \\
\hline Cumhur İttifak1 (Ak Parti-MHP) & 12 & 4,7 & 91,5 \\
\hline IYİ Parti & 10 & 3,9 & 95,3 \\
\hline Millet İttifak1 (CHP-IYI Parti) & 10 & 3,9 & 99,2 \\
\hline HDP & 1 & 0,4 & 99,6 \\
\hline Saadet Partisi & 1 & 0,4 & 100,0 \\
\hline Toplam & $\mathbf{2 5 8}$ & $\mathbf{1 0 0 , 0}$ & \\
\hline
\end{tabular}

Seçim haberlerine konu olan partilerin yer aldı̆̆1 tablo incelendiğinde, haberlerin yüzde 42,6'sında Ak Parti, yüzde 34,1'inde CHP, yüzde 10,1'inde MHP, yüzde 4,7'sinde AK Parti ve MHP'nin oluşturmuş olduğu Cumhur İttifakı'na, yüzde 3,9'unda IYİ Parti'ye, yine yüzde 3,9'unda CHP ve IYYI Parti'nin oluşturmuş olduğu Millet İttifakı'na, yüzde 0,4'ün de HDP’ye ve yine 0,4'ünde Saadet Partisi'ne yer verilmiştir. Sonuçlara bakıldığında, AK Parti ve CHP'nin seçim haberlerine daha çok konu oldukları açık bir şekilde görülmektedir.

Tablo 5. Seçim Haberlerinin İçeriğinin Konusu

\begin{tabular}{|c|c|c|c|}
\hline Konular & Say1 & Yüzde & Toplamlı Yüzde \\
\hline Yerel Seçim-Aday & 83 & 32,2 & 32,2 \\
\hline Terör & 33 & 12,8 & 45.0 \\
\hline Politika & 30 & 11,6 & 56.6 \\
\hline Yolsuzluk & 23 & 8,9 & 65.5 \\
\hline Ekonomi & 20 & 7,8 & 73,3 \\
\hline Birden çok konu & 19 & 7,4 & 80,6 \\
\hline Milli Birlik ve Beraberlik & 11 & 4,3 & 84,9 \\
\hline Din & 10 & 3,9 & 88,8 \\
\hline Milli Mesele & 8 & 3,1 & 91,9 \\
\hline Tarım & 4 & 1,6 & 93,4 \\
\hline Ulaşım & 4 & 1,6 & 95,0 \\
\hline Barınm-Konut & 3 & 1,2 & 96,1 \\
\hline Kültür-Sanat & 3 & 1,2 & 97,3 \\
\hline İşsizlik & 3 & 1,2 & 98,4 \\
\hline Engelliler & 1 & 0,4 & 98,8 \\
\hline Diş Politika & 1 & 0,4 & 99,2 \\
\hline Teknoloji (Illetişim) & 1 & 0,4 & 99,6 \\
\hline Sağlık & 1 & 0,4 & 100,0 \\
\hline Toplam & $\mathbf{2 5 8}$ & $\mathbf{1 0 0 , 0}$ & \\
\hline
\end{tabular}

Gazetelerde yayınlanan seçim haberlerinin içeriğinin incelendiği tabloda, en çok haber yüzde 32,2 yerel seçim-adaylar, yüzde 12,8 terör, yüzde 11,6 ile politika konularında olduğu görülmektedir. Aynı tabloya 
göre en az konu edinen konuların yüzde 0,4 'er ile engelliler, diş politika, teknoloji (iletişim) ve sağllk olduğu tespit edilmiştir. 1

Tablo 6. Seçim Haberlerine Konu Olan Siyasi Aktör

\begin{tabular}{|c|c|c|c|}
\hline Siyasi Aktör & Say1 & Yüzde & Toplamlı Yüzde \\
\hline Parti Genel Başkanı & 158 & 61,2 & 61,2 \\
\hline Belediye Başkan Aday1 & 74 & 28,7 & 89,9 \\
\hline Siyasi Aktör & 15 & 5,8 & 95,7 \\
\hline Siyasi Aktöre Yer Verilmemiş & 11 & 4,3 & 100,0 \\
\hline Toplam & $\mathbf{2 5 8}$ & $\mathbf{1 0 0 , 0}$ & \\
\hline
\end{tabular}

31 Mart 2019 Yerel Seçimleri'nde gazetelerde yer alan seçim haberlerine konu olan siyasi aktöre bakıldığında, yüzde 61,2'sinde parti genel başkanı, yüzde 28,7'sinde belediye başkan adayı, yüzde 5,8'inde siyasi aktöre yer verildiği, yüzde 4,3'ünde ise siyasi aktöre yer verilmediği görülmüştür. Sonuçlara bakıldığında yerel seçim haberlerinde adaylardan çok daha fazla parti genel başkanına yer verildiği açıkça görülmektedir.

Tablo 7. Seçim Haberlerinin Anlatım Tarzı ve Üslubu

\begin{tabular}{|c|c|c|c|}
\hline Anlatım Tarzı ve Üslubu & Say1 & Yüzde & Toplamlı Yüzde \\
\hline Eleştirel-Suçlayıc1 & 115 & 44,6 & 44,6 \\
\hline Bilgilendirici & 93 & 36,0 & 80,6 \\
\hline Tavsiye ve Öneri Verici & 26 & 10,1 & 90,7 \\
\hline Kayg1 Uyandırıc1-Tehdit Edici & 14 & 5,4 & 96,1 \\
\hline Tanıtıc1 & 8 & 3,1 & 99,2 \\
\hline Abartılı & 2 & 0,8 & 100,0 \\
\hline Toplam & $\mathbf{2 5 8}$ & $\mathbf{1 0 0 , 0}$ & \\
\hline
\end{tabular}

Gazetelerde yer alan haberlerin anlatım tarzı ve üslubu incelendiğinde; yüzde 44,6'nın eleştirel-suçlayıcı, yüzde 36'sının bilgilendirici, yüzde 10,1'inin tavsiye ve öneri verici, yüzde 5,4'ünün kayg1 uyandırıc1-tehdit edici, yüzde 3,1'inin tanıtıcı, yüzde 0,8 'inin ise abartılı şekilde konuyu ele aldıkları bulgulanmıştır. Analiz sonuçlarına göre haberlerin anlatım tarzı ve üslubunun daha çok eleştirel-suçlayıcı ve bilgilendirici nitelikte olduğu görülmektedir.

Tablo 8. Seçim Haberlerinde Partiye Yaklaşım

\begin{tabular}{|c|c|c|c|}
\hline Partiye yaklaşım & Say1 & Yüzde & Toplaml Yüzde \\
\hline Nötr & 204 & 79,1 & 79,1 \\
\hline Olumsuz & 30 & 11,6 & 90,7 \\
\hline Olumlu & 24 & 9,3 & 100,0 \\
\hline Toplam & $\mathbf{2 5 8}$ & $\mathbf{1 0 0 , 0}$ & \\
\hline
\end{tabular}

Gazetelerin seçim haberlerinde partiye yaklaşımının incelendiği tabloya göre, haberlerin yüzde 79 , 1'inde nötr, yüzde 11,6'sinda olumsuz, yüzde 9,3'ünde ise olumlu yaklaşım sergilenmiştir. Sonuçlara bakıldığında haberlerin büyük bir oranında nötr bir yaklaşım sergilendiği görülmüştür.

Tablo 9. Seçim Haberlerinde Yorum Durumu

\begin{tabular}{|c|c|c|c|}
\hline Yorum durumu & Say1 & Yüzde & Toplamlı Yüzde \\
\hline Var & 190 & 73,6 & 73,6 \\
\hline Yok & 68 & 26,4 & 100,0 \\
\hline Toplam & $\mathbf{2 5 8}$ & $\mathbf{1 0 0 , 0}$ & \\
\hline
\end{tabular}

Gazetelerde yer alan seçim haberlerinde yorum durumuna bakıldığında; haberlerin yüzde 73,6'sında yoruma yer verilirken, yüzde 26,4'ünde ise yoruma yer verilmemiștir. Sonuçlara göre haberlerin büyük bir oranında yorum yapıldığı görülmektedir. Bu durumda gazetelerin seçimle ilgili yayınladıkları haberlerde, haberin en önemli nitelikleri arasında gösterilen objektiflik ilkesi ile çeliştĭgi söylenebilir. 
Tablo 10. Seçim Haberlerinin Kaynağ1

\begin{tabular}{|c|c|c|c|}
\hline Haber kaynağ1 & Say1 & Yüzde & Toplamlı Yüzde \\
\hline Muhabir & 167 & 64,7 & 64,7 \\
\hline Haber Ajans1 & 45 & 17,4 & 82,2 \\
\hline Belirsiz & 18 & 7,0 & 89,1 \\
\hline Köşe yazar1 & 15 & 5,8 & 95,0 \\
\hline Medya merkezi & 18 & 5,0 & 100,0 \\
\hline Toplam & $\mathbf{2 5 8}$ & $\mathbf{1 0 0 , 0}$ & \\
\hline
\end{tabular}

Seçim haberlerinin kaynağına ilişkin tabloya göre, kaynak olarak haberlerin yüzde 64,7'sinde muhabir, yüzde 17,4'ünde haber ajansı, yüzde 7'inde belirsiz, yüzde 5,8'inde köşe yazarı, yüzde 5 'inde ise medya merkezi kullanılmıstır.

Tablo 11. Seçim Haberlerinin İçeriğinin Kaynağ1

\begin{tabular}{|c|c|c|c|}
\hline Haber içeriğinin kaynağı & Say1 & Yüzde & Toplamlı Yüzde \\
\hline Habere konu olan adayın/partinin görüşü & 201 & 77,9 & 77,9 \\
\hline Haber muhabire dayanıyor & 31 & 12,0 & 89,9 \\
\hline Haber siyasetçiye dayanıyor & 16 & 6,2 & 96,1 \\
\hline Haber vatandaşa dayanıyor & 7 & 2,7 & 98,8 \\
\hline Haber belgelere dayanıyor & 3 & 1,2 & 100,0 \\
\hline Toplam & $\mathbf{2 5 8}$ & $\mathbf{1 0 0 , 0}$ & \\
\hline
\end{tabular}

Haber içeriklerinin dayandığ kaynağa bakıldığında, içeriğin yüzde 77,9'unda habere konu olan aday ya da partinin görüşüne, yüzde 12 'sinde muhabire, yüzde 6,2'sinde siyasetçiye, yüzde 2,7'sinde vatandaşa, yüzde 1,2'sinde ise belgelere dayandığ1 analiz edilmiştir.

Tablo 12. Seçim Haberlerinde Fotoğraf Kullanımı

\begin{tabular}{|c|c|c|c|}
\hline Fotoğraf kullanımı & Say1 & Yüzde & Toplamlı Yüzde \\
\hline Var & 250 & 96,9 & 96,9 \\
\hline Yok & 8 & 3,1 & 100,0 \\
\hline Toplam & $\mathbf{2 5 8}$ & $\mathbf{1 0 0 , 0}$ & \\
\hline
\end{tabular}

Seçim döneminde gazetelerde yayınlanan seçim içerikli haberlerin analizine bakıldığında, haberlerin yüzde 96,9 gibi büyük oranında fotoğraf kullanılırken, yüzde 3,1'inde ise fotoğraf kullanılmadığı tespit edilmiştir.

Tablo 13. Seçim Haberlerinin Görselinde Kullanılan Siyasi Aktör

\begin{tabular}{|c|c|c|c|}
\hline Görselde Aktör Kullanımı & Sayı & Yüzde & Toplamlı Yüzde \\
\hline Parti Genel Başkanı & 155 & 60,1 & 60,1 \\
\hline Belediye Başkanı & 72 & 27,9 & 88,0 \\
\hline Siyasi aktöre yer verilmemiş & 18 & 7,0 & 95,0 \\
\hline Siyasi aktör & 13 & 5,0 & 100,0 \\
\hline Toplam & $\mathbf{2 5 8}$ & $\mathbf{1 0 0 , 0}$ & \\
\hline
\end{tabular}

Seçim haberlerinde kullanılan görseldeki siyasi aktörle ilgili tabloya göre, haberlerin yüzde 60,1'inde parti genel başkanına, yüzde 27,9'unda belediye başkanına, yüzde 5'inde herhangi bir siyasi aktöre yer verilirken, yüzde 7'sinde ise siyasi aktöre yer verilmediği bulgulanmıştır. Analiz sonuçlarına göre incelenen haberlerin önemli bir yüzdesinde görsel olarak parti genel başkanının kullanıldığı görülmüştür. 
Tablo 14. Gazetede Yayınlanan Haberlerde Partive Yaklașım

\begin{tabular}{|c|c|c|c|c|c|}
\hline \multirow{2}{*}{ Gazete } & \multirow{2}{*}{ Parti } & \multicolumn{3}{|c|}{ Haberin Partiye Yaklaşımı } & \multirow[b]{2}{*}{ Toplam } \\
\hline & & Olumlu & Olumsuz & Nötr & \\
\hline \multirow{27}{*}{$\begin{array}{l}\text { 覀 } \\
\text { 帛 }\end{array}$} & \multirow{3}{*}{ AK Parti } & 12 & 0 & 28 & 40 \\
\hline & & $30,0 \%$ & $0,0 \%$ & $70,0 \%$ & $100,0 \%$ \\
\hline & & $80,0 \%$ & $0,0 \%$ & $60,9 \%$ & $51,3 \%$ \\
\hline & \multirow{3}{*}{ CHP } & 0 & 17 & 3 & 20 \\
\hline & & $0,0 \%$ & $85,0 \%$ & $15,0 \%$ & $100,0 \%$ \\
\hline & & $0,0 \%$ & $100,0 \%$ & $6,5 \%$ & $25,6 \%$ \\
\hline & \multirow{3}{*}{ MHP } & 0 & 0 & 14 & 14 \\
\hline & & $0,0 \%$ & $0,0 \%$ & $100,0 \%$ & $100,0 \%$ \\
\hline & & $0,0 \%$ & $0,0 \%$ & $30,4 \%$ & $17,9 \%$ \\
\hline & \multirow{3}{*}{ Cumhur İttifakı (AK Parti-MHP) } & 3 & 0 & 1 & 4 \\
\hline & & $75,0 \%$ & $0,0 \%$ & $25,0 \%$ & $100,0 \%$ \\
\hline & & $20,0 \%$ & $0,0 \%$ & $2,2 \%$ & $5,1 \%$ \\
\hline & \multirow{3}{*}{ İYİ Parti } & 0 & 0 & 0 & 0 \\
\hline & & $0,0 \%$ & $0,0 \%$ & $0,0 \%$ & $0,0 \%$ \\
\hline & & $0,0 \%$ & $0,0 \%$ & $0,0 \%$ & $0,0 \%$ \\
\hline & \multirow{3}{*}{ HDP } & 0 & 0 & 0 & 0 \\
\hline & & $0,0 \%$ & $0,0 \%$ & $0,0 \%$ & $0,0 \%$ \\
\hline & & $0,0 \%$ & $0,0 \%$ & $0,0 \%$ & $0,0 \%$ \\
\hline & \multirow{3}{*}{ Saadet Partisi } & 0 & 0 & 0 & 0 \\
\hline & & $0,0 \%$ & $0,0 \%$ & $0,0 \%$ & $0,0 \%$ \\
\hline & & $0,0 \%$ & $0,0 \%$ & $0,0 \%$ & $0,0 \%$ \\
\hline & \multirow{3}{*}{ Millet İttifakı (CHP-IYİ Parti) } & 0 & 0 & 0 & 0 \\
\hline & & $0,0 \%$ & $0,0 \%$ & $0,0 \%$ & $0,0 \%$ \\
\hline & & $0,0 \%$ & $0,0 \%$ & $0,0 \%$ & $0,0 \%$ \\
\hline & \multirow{3}{*}{ Toplam } & 15 & 17 & 46 & 78 \\
\hline & & $19,2 \%$ & $21,8 \%$ & $59,0 \%$ & $100,0 \%$ \\
\hline & & $100,0 \%$ & $100,0 \%$ & $100,0 \%$ & $100,0 \%$ \\
\hline \multirow{27}{*}{ 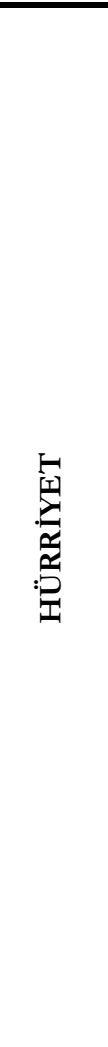 } & \multirow{3}{*}{ AK Parti } & 0 & 0 & 33 & 33 \\
\hline & & $0,0 \%$ & $0,0 \%$ & $100,0 \%$ & $100,0 \%$ \\
\hline & & $0,0 \%$ & $0,0 \%$ & $45,8 \%$ & $44,6 \%$ \\
\hline & \multirow{3}{*}{ CHP } & 0 & 2 & 26 & 28 \\
\hline & & $0,0 \%$ & $7,1 \%$ & $92,9 \%$ & $100,0 \%$ \\
\hline & & $0,0 \%$ & $100,0 \%$ & $36,1 \%$ & $37,8 \%$ \\
\hline & \multirow{3}{*}{ MHP } & 0 & 0 & 3 & 3 \\
\hline & & $0,0 \%$ & $0,0 \%$ & $100,0 \%$ & $100,0 \%$ \\
\hline & & $0,0 \%$ & $0,0 \%$ & $4,2 \%$ & $4,1 \%$ \\
\hline & & 0 & 0 & 1 & 1 \\
\hline & IYYİ Parti & $0,0 \%$ & $0,0 \%$ & $100,0 \%$ & $100,0 \%$ \\
\hline & & $0,0 \%$ & $0,0 \%$ & $1,4 \%$ & $1,4 \%$ \\
\hline & & 0 & 0 & 1 & 1 \\
\hline & HDP & $0,0 \%$ & $0,0 \%$ & $100,0 \%$ & $100,0 \%$ \\
\hline & & $0,0 \%$ & $100,0 \%$ & $1,4 \%$ & $1,4 \%$ \\
\hline & & 0 & 0 & 5 & 5 \\
\hline & Millet İttifakı (CHP-IYİ Parti) & $0,0 \%$ & $0,0 \%$ & $100,0 \%$ & $100,0 \%$ \\
\hline & & $0,0 \%$ & $0,0 \%$ & $6,9 \%$ & $6,8 \%$ \\
\hline & & 0 & 0 & 3 & 3 \\
\hline & Cumhur İttifak1 (AK Parti-MHP) & $0,0 \%$ & $0,0 \%$ & $100,0 \%$ & $100,0 \%$ \\
\hline & & $0,0 \%$ & $0,0 \%$ & $4,2 \%$ & $4,1 \%$ \\
\hline & & 0 & 0 & 0 & 0 \\
\hline & Saadet Partisi & $0,0 \%$ & $0,0 \%$ & $0,0 \%$ & $0,0 \%$ \\
\hline & & $0,0 \%$ & $0,0 \%$ & $0,0 \%$ & $0,0 \%$ \\
\hline & & 0 & 2 & 72 & 74 \\
\hline & Toplam & $\overline{0,0 \%}$ & $2,7 \%$ & $97,3 \%$ & $100,0 \%$ \\
\hline & & $0,0 \%$ & $100,0 \%$ & $100,0 \%$ & $100,0 \%$ \\
\hline
\end{tabular}


Haberde Objektiflik Tartışmaları: 31 Mart 2019 Yerel Seçimleri Örneği

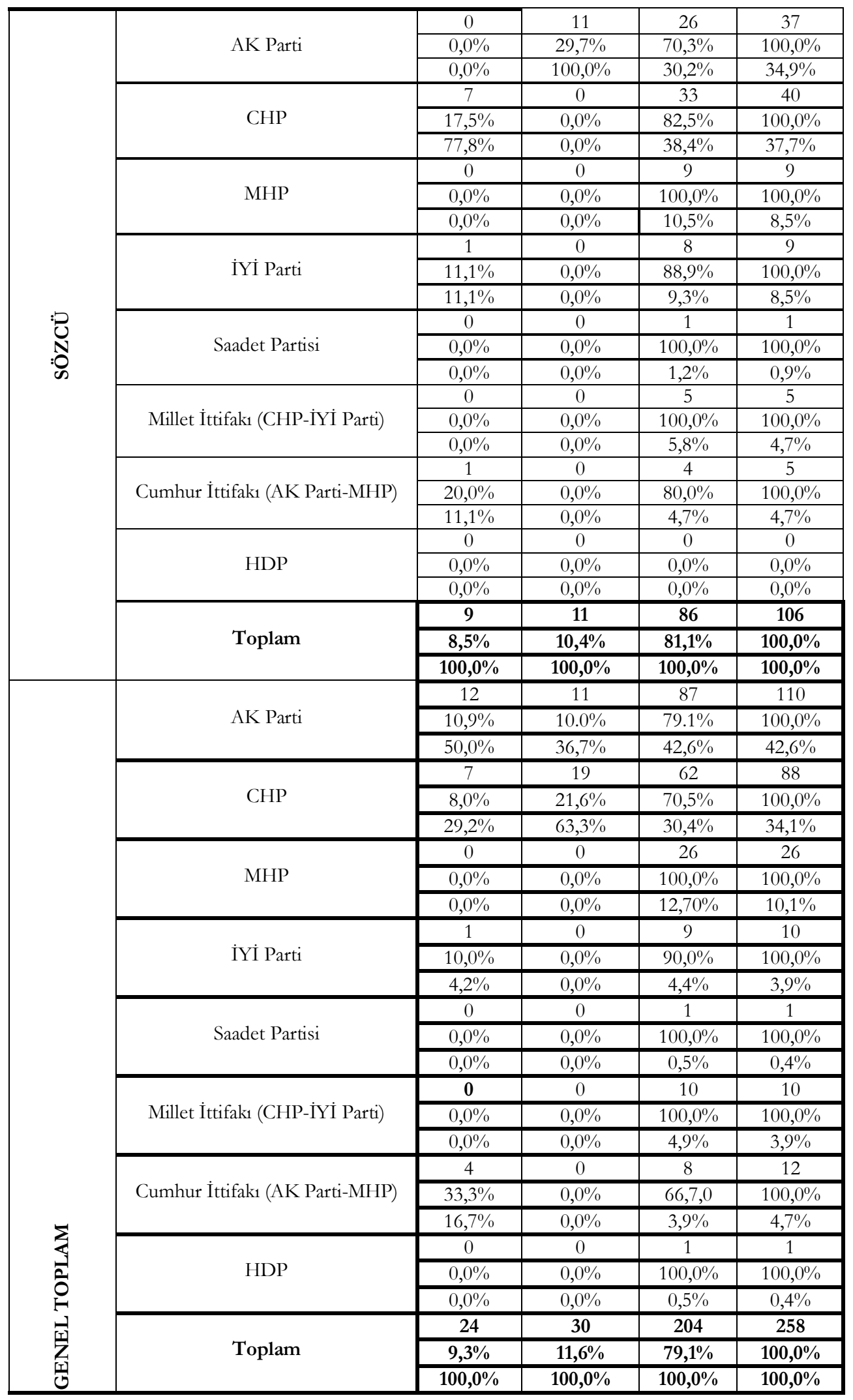


Tablo 14’te 31 Mart 2019 Yerel Seçimleri'nde Sabah, Hürriyet ve Sözcü gazetelerinin seçim öncesi yayınladıkları haberlerde partilere yaklaşımının analizleri bulunmaktadır. Analiz sonuçlarına göre üç gazetede toplamda yayınlanan 258 haberin yüzde 79,1’inde partilere nötr yaklaşıldığ1 görülmüştür. Sabah gazetesinde partilere yönelik toplam 78 haber yayınladığ1, bu haberlerin yüzde 19,2'sine olumlu, yüzde 21,8'ine olumsuz, yüzde 59'una ise nötr yaklaşıldığı bulgulanmıştır.

AK Parti'ye ait 40 haberin yüzde 30'una olumlu, yüzde 70'ine ise nötr biçimde yaklaşan Sabah gazetesi; CHP'ye ait 20 haberini ise yüzde 85 olumsuz, yüzde 15 ise nötr olarak gerçekleştirmiştir. Sabah gazetesi, MHP'ye yönelik ise 14 haberin tamamına nötr yaklaşmıştır. Ayrıca Cumhur İttifakı'na (AK Parti-MHP) yönelik 4 haberin ise yüzde 75 'ine olumlu, yüzde 25 'ine ise nötr yaklaşılmıştır. Sabah gazetesi 4 haftalık seçim döneminde, IYİ Parti, HDP, Saadet Partisi ve Millet İttifakı ile ilgili seçim konulu hiçbir habere yer vermediği de tespit edilmiştir.

Hürriyet gazetesinde yayınlanan 74 haberin ise yüzde 2,7'sine olumsuz, yüzde 97,3'üne ise nötr yaklaşıldığ görülmektedir. Gazete, AK Parti, MHP, IYİ Parti, HDP, Millet İttifak1 (CHP-iYİ Parti), ve Cumhur İttifakı (AK Parti-MHP) haberlerinin tamamına nötr yaklaşmış; CHP haberlerinin ise yüzde 92,9'una nötr, yüzde 7,2'sine ise olumsuz yaklaşımla yer verilmiştir. Hürriyet gazetesi bu dönemde seçimle alakalı sadece Saadet Partisi ile ilgili haber yayınlamamıştır.

Sözcü gazetesinde yayınlanan 106 haberin ise yüzde 8,5'inde olumlu, yüzde 10,4'ünde olumsuz, yüzde 81,1 'inde ise nötr yaklaşım sergilenmiştir. AK Parti'ye ait 37 haberin yüzde 29,7'sinde olumsuz, yüzde 70,3 'ünde nötr tutum sergilendiği görülmüştür. CHP'ye ait 40 haberin yüzde 17,5 'inde olumlu, yüzde 82,5 'inde ise nötr yaklaşım sergilenmiştir. Sözcü gazetesi ise bu dönemde sadece HDP ile ilgili haber yayınlamadığ1 görülmektedir.

Tablo 15. Gazetede Yayınlanan Haberlerde Yorum Durumu

\begin{tabular}{|c|c|c|c|c|}
\hline \multirow{2}{*}{ Gazete } & \multirow{2}{*}{ Parti } & \multicolumn{2}{|c|}{ Haberde Yorum Durumu } & \multirow{2}{*}{ Toplam } \\
\hline & & Var & Yok & \\
\hline \multirow{27}{*}{$\underset{\infty}{\stackrel{T}{\infty}}$} & \multirow{3}{*}{ AK Parti } & 17 & 23 & 40 \\
\hline & & $42,5 \%$ & $57,5 \%$ & $100,0 \%$ \\
\hline & & $44,7 \%$ & $57,5 \%$ & $51,3 \%$ \\
\hline & \multirow{3}{*}{ CHP } & 17 & 3 & 20 \\
\hline & & $85,0 \%$ & $15,0 \%$ & $100,0 \%$ \\
\hline & & $44,7 \%$ & $7,5 \%$ & $25,6 \%$ \\
\hline & \multirow{3}{*}{ MHP } & 1 & 13 & 14 \\
\hline & & $7,1 \%$ & $92,9 \%$ & $100,0 \%$ \\
\hline & & $2,6 \%$ & $32,5 \%$ & $17,9 \%$ \\
\hline & \multirow{3}{*}{ Cumhur İttifakı (AK Parti-MHP) } & 3 & 1 & 4 \\
\hline & & $75,0 \%$ & $25,0 \%$ & $100,0^{\circ} \%$ \\
\hline & & $7,9 \%$ & $2,5 \%$ & $5,1 \%$ \\
\hline & \multirow{3}{*}{ IYİ Parti } & 0 & 0 & 0 \\
\hline & & $0,0 \%$ & $0,0 \%$ & $0,0 \%$ \\
\hline & & $0,0 \%$ & $0,0 \%$ & $0,0 \%$ \\
\hline & \multirow{3}{*}{ HDP } & 0 & 0 & 0 \\
\hline & & $0,0 \%$ & $0,0 \%$ & $0,0 \%$ \\
\hline & & $0,0 \%$ & $0,0 \%$ & $0,0 \%$ \\
\hline & \multirow{3}{*}{ Saadet Partisi } & 0 & 0 & 0 \\
\hline & & $0,0 \%$ & $0,0 \%$ & $0,0 \%$ \\
\hline & & $0,0 \%$ & $0,0 \%$ & $0,0 \%$ \\
\hline & \multirow{3}{*}{ Millet İttifakı (CHP-IYYI Parti) } & 0 & 0 & 0 \\
\hline & & $0,0 \%$ & $0,0 \%$ & $0,0 \%$ \\
\hline & & $0,0 \%$ & $0,0 \%$ & $0,0 \%$ \\
\hline & \multirow{3}{*}{ Toplam } & 38 & 40 & 78 \\
\hline & & $48,7 \%$ & $51,3 \%$ & $100,0 \%$ \\
\hline & & $100,0 \%$ & $100,0 \%$ & $100,0 \%$ \\
\hline
\end{tabular}


Haberde Objektiflik Tartışmaları: 31 Mart 2019 Yerel Seçimleri Örneği

\begin{tabular}{|c|c|c|c|c|}
\hline \multirow{27}{*}{ 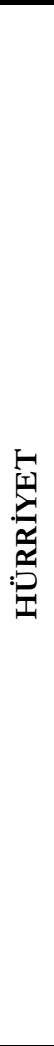 } & \multirow{3}{*}{ AK Parti } & 1 & 32 & 33 \\
\hline & & $3,0 \%$ & $97,0 \%$ & $100,0 \%$ \\
\hline & & $50,0 \%$ & $44,4 \%$ & $44,6 \%$ \\
\hline & \multirow{3}{*}{ CHP } & 1 & 27 & 28 \\
\hline & & $3,6 \%$ & $96,4 \%$ & $100,0 \%$ \\
\hline & & $50,0 \%$ & $37,5 \%$ & $37,8 \%$ \\
\hline & \multirow{3}{*}{ MHP } & 0 & 3 & 3 \\
\hline & & $0,0 \%$ & $100,0 \%$ & $100,0 \%$ \\
\hline & & $0,0 \%$ & $4,2 \%$ & $4,1 \%$ \\
\hline & \multirow{3}{*}{ İYİ Parti } & 0 & 1 & 1 \\
\hline & & $0,0 \%$ & $100,0 \%$ & $100,0 \%$ \\
\hline & & $0,0 \%$ & $1,4 \%$ & $1,4 \%$ \\
\hline & \multirow{3}{*}{ HDP } & 0 & 1 & 1 \\
\hline & & $0,0 \%$ & $100,0 \%$ & $100,0 \%$ \\
\hline & & $0,0 \%$ & $1,4 \%$ & $1,4 \%$ \\
\hline & \multirow{3}{*}{ Millet İttifakı (CHP-IYYI Parti) } & 0 & 5 & 5 \\
\hline & & $0,0 \%$ & $100,0 \%$ & $100,0 \%$ \\
\hline & & $0,0 \%$ & $6,9 \%$ & $6,8 \%$ \\
\hline & \multirow{3}{*}{ Cumhur İttifak1 (AK Parti-MHP) } & 0 & 3 & 3 \\
\hline & & $0,0 \%$ & $100,0 \%$ & $100,0 \%$ \\
\hline & & $0,0 \%$ & $4,2 \%$ & $4,1 \%$ \\
\hline & \multirow{3}{*}{ Saadet Partisi } & 0 & 0 & 0 \\
\hline & & $0,0 \%$ & $0,0 \%$ & $0,0 \%$ \\
\hline & & $0,0 \%$ & $0,0 \%$ & $0,0 \%$ \\
\hline & \multirow{3}{*}{ Toplam } & 2 & 72 & 74 \\
\hline & & $2,7 \%$ & $97,3 \%$ & $100,0 \%$ \\
\hline & & $100,0 \%$ & $100,0 \%$ & $100,0 \%$ \\
\hline \multirow{27}{*}{$\begin{array}{l}\text { : } \\
\text { : } \\
\text { : }\end{array}$} & \multirow{3}{*}{ AK Parti } & 13 & 24 & 37 \\
\hline & & $35,1 \%$ & $64,9 \%$ & $100,0 \%$ \\
\hline & & $46,4 \%$ & $30,8 \%$ & $34,9 \%$ \\
\hline & \multirow{3}{*}{ CHP } & 9 & 31 & 40 \\
\hline & & $22,5 \%$ & $77,5 \%$ & $100,0 \%$ \\
\hline & & $32,1 \%$ & $39,7 \%$ & $37,7 \%$ \\
\hline & \multirow{3}{*}{ MHP } & 1 & 8 & 9 \\
\hline & & $11,1 \%$ & $88,9 \%$ & $100,0 \%$ \\
\hline & & $3,6 \%$ & $10,3 \%$ & $8,5 \%$ \\
\hline & \multirow{3}{*}{ IYYI Parti } & 2 & 7 & 9 \\
\hline & & $22,2 \%$ & $77,8 \%$ & $100,0 \%$ \\
\hline & & $7,1 \%$ & $9,0 \%$ & $8,5 \%$ \\
\hline & \multirow{3}{*}{ Saadet Partisi } & 0 & 1 & 1 \\
\hline & & $0,0 \%$ & $100,0 \%$ & $100,0 \%$ \\
\hline & & $0,0 \%$ & $1,3 \%$ & $0,9 \%$ \\
\hline & \multirow{3}{*}{ Millet İttifakı (CHP-IYİ Parti) } & 1 & 4 & 5 \\
\hline & & $20,0 \%$ & $80,0 \%$ & $100,0 \%$ \\
\hline & & $3,6 \%$ & $5,1 \%$ & $4,7 \%$ \\
\hline & \multirow{3}{*}{ Cumhur İttifak1 (AK Parti-MHP) } & 2 & 3 & 5 \\
\hline & & $40,0 \%$ & $60,0 \%$ & $100,0 \%$ \\
\hline & & $7,1 \%$ & $3,8 \%$ & $4,7 \%$ \\
\hline & \multirow{3}{*}{ HDP } & 0 & 0 & 0 \\
\hline & & $0,0 \%$ & $0,0 \%$ & $0,0 \%$ \\
\hline & & $0,0 \%$ & $0,0 \%$ & $0,0 \%$ \\
\hline & \multirow{3}{*}{ Toplam } & 28 & 78 & 106 \\
\hline & & $26,4 \%$ & $73,6 \%$ & $100,0 \%$ \\
\hline & & $100,0 \%$ & $100,0 \%$ & $100,0 \%$ \\
\hline
\end{tabular}

Tablo 15’te Sabah, Hürriyet ve Sözcü gazetelerinin 31 Mart 2019 Yerel Seçimleri’nde partilere yönelik haberlerde yorum durumuna ilişkin bilgiler yer almaktadır. Sabah gazetesinde yayınlanan AK Parti 
haberlerinin yüzde 42,5'inde yorum yapilmış, yüzde 57,5'inde ise yoruma yer verilmemiştir. CHP haberlerinin ise yüzde 85 'inde yorum yapıldığı, yüzde 15 ’nde ise yoruma başvurulmadığ görülmüştür. MHP haberlerinin yüzde 7,1'inde yorum yapılmıs, yüzde 92,9'unda ise yorum yapılmamıştır. Cumhur İttifak1 (AK Parti-MHP) haberlerinin ise yüzde 75 'inde yoruma yer verilirken, yüzde 25 'inde ise yoruma yer verilmediği bulgulanmıştır.

Hürriyet gazetesinde yayınlanan 33 adet AK Parti haberinin yüzde 3'ünde yorum yapılmış, yüzde 97'sinde yorum yapılmamıştır. CHP'ye ait 28 haberin ise yüzde 3,6'sında yorum yapıldığı, yüzde 96,4'ünde ise yorum yapılmadığı görülmektedir. Yine MHP, IYİ Parti, HDP, Millet İttifakı (CHP-IYYİ Parti), Cumhur İttifakı (AK Parti-MHP) haberlerinde ise yorum yapılmadığı tespit edilmiştir.

Sözcü gazetesinde yayınlanan 37 AK Parti haberinin yüzde 35,1'inde yorum yapıldı̆̆1, yüzde 64,9'unda ise yorum yapılmadığ1; CHP'ye ait 40 haberin yüzde 22,5'inde yorum yapıldığı, yüzde 77,5'inde ise yorum yapılmadığ1 görülmektedir. MHP’ye ait 9 haberin yüzde 11,1'inde; IYİ Parti'ye ait 9 haberin yüzde 22,2'sinde; Millet İttifakı'na (CHP-iYİ Parti) ait 5 haberin yüzde 20'sinde; Cumhur İttifakı'na (AK PartiMHP) ait haberlerin yüzde 40'ında yorum yapilırken MHP haberlerinin yüzde 88,9'unda; IYİ Parti haberlerinin yüzde 77,8'inde; Millet İttifak1 (CHP-IYİ Parti) haberlerinin yüzde 80'inde; Cumhur İttifak1 (AK Parti-MHP) haberlerinin ise yüzde 60'ında yorum yapılmıştır.

Tablo 16. Gazetede Yayınlanan Haberin Gazete Sayfasındaki Konumu

\begin{tabular}{|c|c|c|c|c|c|}
\hline \multirow[b]{2}{*}{ Gazete } & \multirow[b]{2}{*}{ Parti } & \multicolumn{3}{|c|}{ Haberin sayfadaki konumu } & \multirow[b]{2}{*}{ Toplam } \\
\hline & & Manşet & Sürmanşet & $\begin{array}{c}\text { Sayfanin } \\
\text { muhtelif } \\
\text { yerleri }\end{array}$ & \\
\hline \multirow{27}{*}{ 焉 } & \multirow{3}{*}{ AK Parti } & 8 & 0 & 32 & 40 \\
\hline & & $20,0 \%$ & $0,0 \%$ & $80,0 \%$ & $100,0 \%$ \\
\hline & & $47,1 \%$ & $0,0 \%$ & $52,5 \%$ & $51,3 \%$ \\
\hline & \multirow{3}{*}{ CHP } & 6 & 0 & 14 & 20 \\
\hline & & $30,0 \%$ & $0,0 \%$ & $70,0 \%$ & $100,0 \%$ \\
\hline & & $35,3 \%$ & $0,0 \%$ & $23,0 \%$ & $25,6 \%$ \\
\hline & \multirow{3}{*}{ MHP } & 1 & 0 & 13 & 14 \\
\hline & & $7,1 \%$ & $0,0 \%$ & 92,9 & $100,0 \%$ \\
\hline & & $5,9 \%$ & $0,0 \%$ & 21,3 & $17,9 \%$ \\
\hline & \multirow{3}{*}{ Cumhur İttifak1 (AK Parti-MHP) } & 2 & 0 & 2 & 4 \\
\hline & & $50,0 \%$ & $0,0 \%$ & $50,0 \%$ & $100,0 \%$ \\
\hline & & $11,8 \%$ & $0,0 \%$ & $3,3 \%$ & $5,1 \%$ \\
\hline & \multirow{3}{*}{ IYİ Parti } & 0 & 0 & 0 & 0 \\
\hline & & $0,0 \%$ & $0,0 \%$ & $0,0 \%$ & $0,0 \%$ \\
\hline & & $0,0 \%$ & $0,0 \%$ & $0,0 \%$ & $0,0 \%$ \\
\hline & \multirow{3}{*}{ HDP } & 0 & 0 & 0 & 0 \\
\hline & & $0,0 \%$ & $0,0 \%$ & $0,0 \%$ & $0,0 \%$ \\
\hline & & $0,0 \%$ & $0,0 \%$ & $0,0 \%$ & $0,0 \%$ \\
\hline & \multirow{3}{*}{ Saadet Partisi } & 0 & 0 & 0 & 0 \\
\hline & & $0,0 \%$ & $0,0 \%$ & $0,0 \%$ & $0,0 \%$ \\
\hline & & $0,0 \%$ & $0,0 \%$ & $0,0 \%$ & $0,0 \%$ \\
\hline & \multirow{3}{*}{ Millet İttifakı (CHP-IYİ Parti) } & 0 & 0 & 0 & 0 \\
\hline & & $0,0 \%$ & $0,0 \%$ & $0,0 \%$ & $0,0 \%$ \\
\hline & & $0,0 \%$ & $0,0 \%$ & $0,0 \%$ & $0,0 \%$ \\
\hline & \multirow{3}{*}{ Toplam } & 17 & 0 & 61 & 78 \\
\hline & & $21,8 \%$ & $0,0 \%$ & $78,2 \%$ & $100,0 \%$ \\
\hline & & $100,0 \%$ & $0,0 \%$ & $100,0 \%$ & $100,0 \%$ \\
\hline
\end{tabular}


Haberde Objektiflik Tartışmaları: 31 Mart 2019 Yerel Seçimleri Örneği

\begin{tabular}{|c|c|c|c|c|c|}
\hline \multirow{27}{*}{ 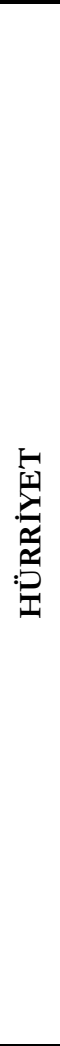 } & \multirow{3}{*}{ AK Parti } & 6 & 0 & 27 & 33 \\
\hline & & $18,2 \%$ & $0,0 \%$ & $81,8 \%$ & $100,0 \%$ \\
\hline & & $75,0 \%$ & $0,0 \%$ & $40,9 \%$ & $44,6 \%$ \\
\hline & \multirow{3}{*}{ CHP } & 0 & 0 & 28 & 28 \\
\hline & & $0,0 \%$ & $0,0 \%$ & $100,0 \%$ & $100,0 \%$ \\
\hline & & $0,0 \%$ & $0,0 \%$ & $42,4 \%$ & $37,8 \%$ \\
\hline & \multirow{3}{*}{ MHP } & 0 & 0 & 3 & 3 \\
\hline & & $0,0 \%$ & $0,0 \%$ & $100,0 \%$ & $100,0 \%$ \\
\hline & & $0,0 \%$ & $0,0 \%$ & $4,5 \%$ & $4,1 \%$ \\
\hline & \multirow{3}{*}{ İYİ Parti } & 0 & 0 & 1 & 1 \\
\hline & & $0,0 \%$ & $0,0 \%$ & $100,0 \%$ & $100,0 \%$ \\
\hline & & $0,0 \%$ & $0,0 \%$ & $1,5 \%$ & $1,4 \%$ \\
\hline & \multirow{3}{*}{ HDP } & 0 & 0 & 1 & 1 \\
\hline & & $0,0 \%$ & $0,0 \%$ & $100,0 \%$ & $100,0 \%$ \\
\hline & & $0,0 \%$ & $0,0 \%$ & $1,5 \%$ & $1,4 \%$ \\
\hline & \multirow{3}{*}{ Millet İttifakı (CHP-İYİ Parti) } & 0 & 0 & 5 & 5 \\
\hline & & $0,0 \%$ & $0,0 \%$ & $100,0 \%$ & $100,0 \%$ \\
\hline & & $0,0 \%$ & $0,0 \%$ & $7,6 \%$ & $6,8 \%$ \\
\hline & \multirow{3}{*}{ Cumhur İttifakı (AK Parti-MHP) } & 2 & 0 & 1 & 3 \\
\hline & & $66,7 \%$ & $0,0 \%$ & $33,3 \%$ & $100,0 \%$ \\
\hline & & $25,0 \%$ & $0,0 \%$ & $1,5 \%$ & $4,1 \%$ \\
\hline & \multirow{3}{*}{ Saadet Partisi } & 0 & 0 & 0 & 0 \\
\hline & & $0,0 \%$ & $0,0 \%$ & $0,0 \%$ & $0,0 \%$ \\
\hline & & $0,0 \%$ & $0,0 \%$ & $0,0 \%$ & $0,0 \%$ \\
\hline & \multirow{3}{*}{ Toplam } & 8 & 0 & 66 & 74 \\
\hline & & $10,8 \%$ & $0,0 \%$ & $89,2 \%$ & $100,0 \%$ \\
\hline & & $100,0 \%$ & $0,0 \%$ & $100,0 \%$ & $100,0 \%$ \\
\hline \multirow{27}{*}{ 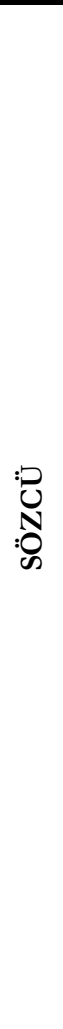 } & \multirow{3}{*}{ AK Parti } & 7 & 2 & 28 & 37 \\
\hline & & $18,9 \%$ & $5,4 \%$ & $75,7 \%$ & $100,0 \%$ \\
\hline & & $41,2 \%$ & $28,6 \%$ & $34,1 \%$ & $34,9 \%$ \\
\hline & \multirow{3}{*}{ CHP } & 5 & 5 & 30 & 40 \\
\hline & & $12,5 \%$ & $12,5 \%$ & $75,0 \%$ & $100,0 \%$ \\
\hline & & $29,4 \%$ & $71,4 \%$ & $36,6 \%$ & $37,7 \%$ \\
\hline & \multirow{3}{*}{ MHP } & 0 & 0 & 9 & 9 \\
\hline & & $0,0 \%$ & $0,0 \%$ & $100,0 \%$ & $100,0 \%$ \\
\hline & & $0,0 \%$ & $0,0 \%$ & $11,0 \%$ & $8,5 \%$ \\
\hline & \multirow{3}{*}{ İYİ Parti } & 3 & 0 & 6 & 9 \\
\hline & & $33,3 \%$ & $0,0 \%$ & $66,7 \%$ & $100,0 \%$ \\
\hline & & $17,6 \%$ & $0,0 \%$ & $7,3 \%$ & $8,5 \%$ \\
\hline & \multirow{3}{*}{ Saadet Partisi } & 0 & 0 & 1 & 1 \\
\hline & & $0,0 \%$ & $0,0 \%$ & $100,0 \%$ & $100,0 \%$ \\
\hline & & $0,0 \%$ & $0,0 \%$ & $1,2 \%$ & $0,9 \%$ \\
\hline & \multirow{3}{*}{ Millet İttifakı (CHP-IYYI Parti) } & 1 & 0 & 4 & 5 \\
\hline & & $20,0 \%$ & $0,0 \%$ & $80,0 \%$ & $100,0 \%$ \\
\hline & & $5,9 \%$ & $0,0 \%$ & $4,9 \%$ & $4,7 \%$ \\
\hline & \multirow{3}{*}{ Cumhur İttifakı (AK Parti-MHP) } & 1 & 0 & 4 & 5 \\
\hline & & $20,0 \%$ & $0,0 \%$ & 80,0 & $100,0 \%$ \\
\hline & & $5,9 \%$ & $0,0 \%$ & $4,9 \%$ & $4,7 \%$ \\
\hline & \multirow{3}{*}{ HDP } & 0 & 0 & 0 & 0 \\
\hline & & $0,0 \%$ & $0,0 \%$ & $0,0 \%$ & $0,0 \%$ \\
\hline & & $0,0 \%$ & $0,0 \%$ & $0,0 \%$ & $0,0 \%$ \\
\hline & & 17 & 7 & 82 & 106 \\
\hline & Toplam & $16,0 \%$ & $6,6 \%$ & $77,4 \%$ & $100,0 \%$ \\
\hline & & $100,0 \%$ & $100,0 \%$ & $100,0 \%$ & $100,0 \%$ \\
\hline
\end{tabular}


Tablo 16'da Sabah, Hürriyet ve Sözcü gazetelerinde siyasi partilere yönelik yayınlanan haberlerin konumuna ilişkin analizler yer almaktadır. Analiz sonuçlarına göre Sabah gazetesinde AK Parti'ye ait yayınlanan 40 haberin yüzde 20'si manşetten, yüzde 80'i ise gazetenin ilk sayfasının muhtelif yerlerinde verilmiştir. CHP’ye ait 20 haberin yüzde 30’u manşetten, yüzde 70’i ise birinci sayfanın muhtelif yerlerinde yayınlanmıştır. MHP'ye ait 14 haberin yüzde 7,1'i manşetten, yüzde 92,9'u ise gazetenin birinci sayfasının muhtelif yerlerinde yayınlandığı görülmüştür. Cumhur İttifakı'na (AK Parti- MHP) ait 4 haberin ise yüzde 50'si manşetten, yüzde 50'si ise ilk sayfanın muhtelif yerlerinden verilmiştir.

Hürriyet gazetesinde yayınlanan haberlerin AK Parti'ye ait 6 haber (yüzde 18,2) ve Cumhur İttifak1'na ait 2 haber (yüzde 66,7) manşetten yayınlanırken diğer haberlerin tamamı ilk sayfanın muhtelif yerlerinde yayınlanmıştır.

Sözcü gazetesinde yayınlanan 106 haberden AK Parti'ye ait 37 haberin yüzde 18,9’u manşetten, yüzde 5,4'ü sürmanşetten, yüzde 75,7'si ise gazetenin birinci sayfasının muhtelif yerlerinde yayınlanmıştır. CHP'ye ait 40 haberin yüzde 12,5’i manşetten, yine yüzde 12,5’i sürmanşetten, yüzde 75’i ise gazetenin ilk sayfasının muhtelif yerlerinde yayınlanmıştır. MHP haberlerinin tamamı gazetenin birinci sayfasının muhtelif yerlerinde yayınlanmıştır. IYİ Parti'ye ait 9 haberin ise yüzde 33,3'ü manşetten, yüzde 66,7'si ilk sayfanın muhtelif yerlerinde yayınlanmıştır.

Tablo 17. Gazetede Yayınlanan Haberin Kaynağ1

\begin{tabular}{|c|c|c|c|c|c|c|c|}
\hline \multirow[b]{2}{*}{ Gazete } & \multirow[b]{2}{*}{ Parti } & \multicolumn{5}{|c|}{ Haberin kaynağ1 } & \multirow[b]{2}{*}{ Toplam } \\
\hline & & Muhabir & $\begin{array}{l}\text { Haber } \\
\text { Ajansi }\end{array}$ & $\begin{array}{c}\text { Medya } \\
\text { Merkezi }\end{array}$ & $\begin{array}{c}\text { Köşe } \\
\text { Yazar1 }\end{array}$ & Belirsiz & \\
\hline \multirow{27}{*}{ 究 } & \multirow{3}{*}{ AK Parti } & 34 & 0 & 2 & 2 & 2 & 40 \\
\hline & & $85,0 \%$ & $0,0 \%$ & $5,0 \%$ & $5,0 \%$ & $5,0 \%$ & $100,0 \%$ \\
\hline & & $55,7 \%$ & $0,0 \%$ & $22,2 \%$ & $66,7 \%$ & $40,0 \%$ & $51,3 \%$ \\
\hline & \multirow{3}{*}{$\mathrm{CHP}$} & 13 & 0 & 5 & 1 & 1 & 20 \\
\hline & & $65,0 \%$ & $0,0 \%$ & $25,0 \%$ & $5,0 \%$ & $5,0 \%$ & $100,0 \%$ \\
\hline & & $21,3 \%$ & $0,0 \%$ & $55,6 \%$ & $33,3 \%$ & $20,0 \%$ & $25,6 \%$ \\
\hline & \multirow{3}{*}{ MHP } & 10 & 0 & 2 & 0 & 2 & 14 \\
\hline & & $71,4 \%$ & $0,0 \%$ & $14,3 \%$ & $0,0 \%$ & $14,3 \%$ & $100,0 \%$ \\
\hline & & $16,4 \%$ & $0,0 \%$ & $22,2 \%$ & $0,0 \%$ & $40,0 \%$ & $17,9 \%$ \\
\hline & \multirow{3}{*}{ Cumhur İttifakı (AK Parti-MHP) } & 4 & 0 & 0 & 0 & 0 & 4 \\
\hline & & $100,0 \%$ & $0,0 \%$ & $0,0 \%$ & $0,0 \%$ & $0,0 \%$ & $100,0 \%$ \\
\hline & & $6,6 \%$ & $0,0 \%$ & $0,0 \%$ & $0,0 \%$ & $0,0 \%$ & $5,1 \%$ \\
\hline & \multirow{3}{*}{ IYYI Parti } & 0 & 0 & 0 & 0 & 0 & 0 \\
\hline & & $0,0 \%$ & $0,0 \%$ & $0,0 \%$ & $0,0 \%$ & $0,0 \%$ & $0,0 \%$ \\
\hline & & $0,0 \%$ & $0,0 \%$ & $0,0 \%$ & $0,0 \%$ & $0,0 \%$ & $0,0 \%$ \\
\hline & \multirow{3}{*}{ HDP } & 0 & 0 & 0 & 0 & 0 & 0 \\
\hline & & $0,0 \%$ & $0,0 \%$ & $0,0 \%$ & $0,0 \%$ & $0,0 \%$ & $0,0 \%$ \\
\hline & & $0,0 \%$ & $0,0 \%$ & $0,0 \%$ & $0,0 \%$ & $0,0 \%$ & $0,0 \%$ \\
\hline & \multirow{3}{*}{ Saadet Partisi } & 0 & 0 & 0 & 0 & 0 & 0 \\
\hline & & $0,0 \%$ & $0,0 \%$ & $0,0 \%$ & $0,0 \%$ & $0,0 \%$ & $0,0 \%$ \\
\hline & & $0,0 \%$ & $0,0 \%$ & $0,0 \%$ & $0,0 \%$ & $0,0 \%$ & $0,0 \%$ \\
\hline & \multirow{3}{*}{ Millet İttifakı (CHP-IYİ Parti) } & 0 & 0 & 0 & 0 & 0 & 0 \\
\hline & & $0,0 \%$ & $0,0 \%$ & $0,0 \%$ & $0,0 \%$ & $0,0 \%$ & $0,0 \%$ \\
\hline & & $0,0 \%$ & $0,0 \%$ & $0,0 \%$ & $0,0 \%$ & $0,0 \%$ & $0,0 \%$ \\
\hline & \multirow{3}{*}{ Toplam } & 61 & 0 & 9 & 3 & 5 & 78 \\
\hline & & $78,2 \%$ & $0,0 \%$ & $11,5 \%$ & $3,8 \%$ & $6,4 \%$ & $100,0 \%$ \\
\hline & & $100,0 \%$ & $0,0 \%$ & $100,0 \%$ & $100,0 \%$ & $100,0 \%$ & $100,0 \%$ \\
\hline
\end{tabular}


Haberde Objektiflik Tartışmaları: 31 Mart 2019 Yerel Seçimleri Örneği

\begin{tabular}{|c|c|c|c|c|c|c|c|}
\hline \multirow{27}{*}{ 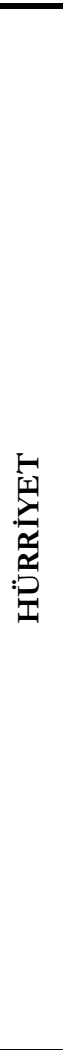 } & \multirow{3}{*}{ AK Parti } & 26 & 3 & 0 & 4 & 0 & 33 \\
\hline & & $78,8 \%$ & $9,1 \%$ & $0,0 \%$ & $12,1 \%$ & $0,0 \%$ & $100,0 \%$ \\
\hline & & $51,0 \%$ & $23,1 \%$ & $0,0 \%$ & $50,0 \%$ & $0,0 \%$ & $44,6 \%$ \\
\hline & \multirow{3}{*}{ CHP } & 16 & 8 & 1 & 3 & 0 & 28 \\
\hline & & $57,1 \%$ & $28,6 \%$ & $3,6 \%$ & $10,7 \%$ & $0,0 \%$ & $100,0 \%$ \\
\hline & & $31,4 \%$ & $61,5 \%$ & $100,0 \%$ & $37,5 \%$ & $0,0 \%$ & $37,8 \%$ \\
\hline & \multirow{3}{*}{ MHP } & 1 & 1 & 0 & 0 & 1 & 3 \\
\hline & & $33,3 \%$ & $33,3 \%$ & $0,0 \%$ & $0,0 \%$ & $33,3 \%$ & $100,0 \%$ \\
\hline & & $2,0 \%$ & $7,7 \%$ & $0,0 \%$ & $0,0 \%$ & $100,0 \%$ & $4,1 \%$ \\
\hline & \multirow{3}{*}{ IYİ Parti } & 1 & 0 & 0 & 0 & 0 & 1 \\
\hline & & $100,0 \%$ & $0,0 \%$ & $0,0 \%$ & $0,0 \%$ & $0,0 \%$ & $100,0 \%$ \\
\hline & & $2,0 \%$ & $0,0 \%$ & $0,0 \%$ & $0,0 \%$ & $0,0 \%$ & $1,4 \%$ \\
\hline & \multirow{3}{*}{ HDP } & 0 & 1 & 0 & 0 & 0 & 1 \\
\hline & & $0,0 \%$ & $100,0 \%$ & $0,0 \%$ & $0,0 \%$ & $0,0 \%$ & $100,0 \%$ \\
\hline & & $0,0 \%$ & $7,7 \%$ & $0,0 \%$ & $0,0 \%$ & $0,0 \%$ & $1,4 \%$ \\
\hline & \multirow{3}{*}{ Millet İttifakı (CHP-İYİ Parti) } & 5 & 0 & 0 & 0 & 0 & 5 \\
\hline & & $100,0 \%$ & $0,0 \%$ & $0,0 \%$ & $0,0 \%$ & $0,0 \%$ & $100,0 \%$ \\
\hline & & $9,8 \%$ & $0,0 \%$ & $0,0 \%$ & $0,0 \%$ & $0,0 \%$ & $6,8 \%$ \\
\hline & \multirow{3}{*}{ Cumhur İttifak1 (AK Parti-MHP) } & 2 & 0 & 0 & 1 & 0 & 3 \\
\hline & & $66,7 \%$ & $0,0 \%$ & $0,0 \%$ & 33,3 & $0,0 \%$ & $100,0 \%$ \\
\hline & & $3,9 \%$ & $0,0 \%$ & $0,0 \%$ & $12,5 \%$ & $0,0 \%$ & $4,1 \%$ \\
\hline & \multirow{3}{*}{ Saadet Partisi } & 0 & 0 & 0 & 0 & 0 & 0 \\
\hline & & $0,0 \%$ & $0,0 \%$ & $0,0 \%$ & $0,0 \%$ & $0,0 \%$ & $0,0 \%$ \\
\hline & & $0,0 \%$ & $0,0 \%$ & $0,0 \%$ & $0,0 \%$ & $0,0 \%$ & $0,0 \%$ \\
\hline & \multirow{3}{*}{ Toplam } & 51 & 13 & 1 & 8 & 1 & 74 \\
\hline & & $68,9 \%$ & $17,6 \%$ & $1,4 \%$ & $10,8 \%$ & $1,4 \%$ & $100,0 \%$ \\
\hline & & $100,0 \%$ & $100,0 \%$ & $100,0 \%$ & $100,0 \%$ & $100,0 \%$ & $100,0 \%$ \\
\hline \multirow{27}{*}{$\begin{array}{l}\text { : } \\
\text { Nֵ } \\
: 0\end{array}$} & \multirow{3}{*}{ AK Parti } & 18 & 13 & 0 & 0 & 6 & 37 \\
\hline & & $48,6 \%$ & $35,1 \%$ & $0,0 \%$ & $0,0 \%$ & $16,2 \%$ & $100,0 \%$ \\
\hline & & $32,7 \%$ & $40,6 \%$ & $0,0 \%$ & $0,0 \%$ & $50,0 \%$ & $34,9 \%$ \\
\hline & \multirow{3}{*}{ CHP } & 30 & 7 & 1 & 2 & 0 & 40 \\
\hline & & $75,0 \%$ & $17,5 \%$ & $2,5 \%$ & $5,0 \%$ & $0,0 \%$ & $100,0 \%$ \\
\hline & & $54,5 \%$ & $21,9 \%$ & $33,3 \%$ & $50,0 \%$ & $0,0 \%$ & $37,7 \%$ \\
\hline & \multirow{3}{*}{ MHP } & 4 & 3 & 1 & 0 & 1 & 9 \\
\hline & & $44,4 \%$ & $33,3 \%$ & $11,1 \%$ & $0,0 \%$ & $11,1 \%$ & $100,0 \%$ \\
\hline & & $7,3 \%$ & $9,4 \%$ & $33,3 \%$ & $0,0 \%$ & $8,3 \%$ & $8,5 \%$ \\
\hline & \multirow{3}{*}{ İYİ Parti } & 1 & 4 & 0 & 0 & 4 & 9 \\
\hline & & $11,1 \%$ & $44,4 \%$ & $0,0 \%$ & $0,0 \%$ & $44,4 \%$ & $100,0 \%$ \\
\hline & & $1,8 \%$ & $12,5 \%$ & $0,0 \%$ & $0,0 \%$ & $33,3 \%$ & $8,5 \%$ \\
\hline & \multirow{3}{*}{ Saadet Partisi } & 1 & 0 & 0 & 0 & 0 & 1 \\
\hline & & $100,0 \%$ & $0,0 \%$ & $0,0 \%$ & $0,0 \%$ & $0,0 \%$ & $100,0 \%$ \\
\hline & & $1,8 \%$ & $0,0 \%$ & $0,0 \%$ & $0,0 \%$ & $0,0 \%$ & $0,9 \%$ \\
\hline & \multirow{3}{*}{ Millet İttifakı (CHP-IYYİ Parti) } & 1 & 3 & 0 & 0 & 1 & 5 \\
\hline & & $20,0 \%$ & $60,0 \%$ & $0,0 \%$ & $0,0 \%$ & $20,0 \%$ & $100,0 \%$ \\
\hline & & $1,8 \%$ & $9,4 \%$ & $0,0 \%$ & $0,0 \%$ & $8,3 \%$ & $4,7 \%$ \\
\hline & \multirow{3}{*}{ Cumhur İttifakı (AK Parti-MHP) } & 0 & 2 & 1 & 2 & 0 & 5 \\
\hline & & $0,0 \%$ & $40,0 \%$ & 20,0 & $40,0 \%$ & $0,0 \%$ & $100,0 \%$ \\
\hline & & $0,0 \%$ & $6,3 \%$ & $33,3 \%$ & $50,0 \%$ & $0,0 \%$ & $4,7 \%$ \\
\hline & & 0 & 0 & 0 & 0 & 0 & 0 \\
\hline & HDP & $0,0 \%$ & $0,0 \%$ & $0,0 \%$ & $0,0 \%$ & $0,0 \%$ & $0,0 \%$ \\
\hline & & $0,0 \%$ & $0,0 \%$ & $0,0 \%$ & $0,0 \%$ & $0,0 \%$ & $0,0 \%$ \\
\hline & & 55 & 32 & 3 & 4 & 12 & 106 \\
\hline & Toplam & $51,9 \%$ & $30,2 \%$ & $2,8 \%$ & $3,8 \%$ & $11,3 \%$ & $100,0 \%$ \\
\hline & & $100,0 \%$ & $100,0 \%$ & $100,0 \%$ & $100,0 \%$ & $100,0 \%$ & $100,0 \%$ \\
\hline
\end{tabular}

Tablo 17'de, 31 Mart 2019 Yerel Seçimleri öncesinde Sabah, Hürriyet ve Sözcü gazetelerinde partilerle ilgili yayınladıklanı haberlerin kaynağına ilişkin analiz sonuçları yer almaktadır. Sonuçlara bakıldığında, 
Sabah gazetesinde AK Parti'ye ait 40 haberin yüzde 85'inde muhabir, yüzde 5'inde medya merkezi yüzde 5 'inde köşe yazarı kaynak olarak kullanılırken yine yüzde 5 'inde ise haber kaynağının belirsiz olduğu bulunmuştur. CHP'ye ait 20 haberin yüzde 65 'inde muhabir, yüzde 25 'inde medya merkezi, yüzde 5 'inde köşe yazarı kaynak olarak kullanılmış ama yüzde 5 'inde ise haberin kaynağının belirsiz olduğu görülmüştür. MHP'ye ait 14 haberin 71,4'ünde muhabir, yüzde 14,3'ünde medya merkezi kullanilırken yüzde 14,3'ünde ise haberin kaynağı belirtilmemiştir. Cumhur İttifakı'na (AK Parti-MHP) ait haberlerin tamamında kaynak olarak muhabir kullanılmışır.

Hürriyet gazetesinde yayınlanan AK Parti haberlerinin yüzde 78,8'inde muhabir, yüzde 9,1'inde haber ajans1, yüzde 12,1'inde köşe yazarı kaynak olarak kullanılmıştır. CHP haberlerinin yüzde 57,1'inde muhabir, yüzde 28,6'sında haber ajansi, yüzde 3,6'sında medya merkezi kaynak olarak kullanılmıştır. IYYI Parti ve Millet İttifakı (CHP-iYİ Parti) haberlerinin tamamında kaynak olarak muhabir kullanılmıştır.

Sözcü gazetesinde yayınlanan toplam 106 haberden AK Parti'ye ait olan 37 haberin yüzde 48,6'sında muhabir, yüzde 35,1'inde haber ajansı kaynak olarak kullanılmış, yüzde 16,2'sinde ise kaynak belirsizdir. CHP'ye ait 40 haberin yüzde 75'inde muhabir, yüzde 17,5'inde haber ajans1, yüzde 2,5'inde medya merkezi, yüzde 5'inde köşe yazarı kaynak olarak kullanılmıştır. MHP'ye ait 9 haberin yüzde 44,4'ünde muhabir, yüzde 33,3'ünde haber ajans1, yüzde 11,1'inde medya merkezi kullanılmış, yine 11,1'inde ise kaynak belirsizdir.

\section{Sonuç ve Öneriler}

Bu çalışmada haber ve haberde objektiflik tartışmaları ele alınmıştır. Konuyu ilişkin literatürde yer alan teorik bilgilerin yanında bu konuda daha önce yapılmış çalışmaların sonuçlarına değinilmiştir. Konunun daha iyi kavranması için örnek olarak 31 Mart 2019 Yerel Seçimleri ele alınmıştır. Analiz için Sabah, Hürriyet ve Sözcü gibi yayın politikaları ve ideolojileri açısından farklılık taşıyan üç gazete seçilmiştir. Bu gazetelerin ilk sayfalarında yayınlanan seçimlere yönelik haberler incelenmiştir. Ayrıca hem konu bütünlüğünü sağlama hem de Türkiye'de seçimlere gidilen süreçte yaşanan önemli olaylara, literatüre kalıc1 ve yeni bilgi sağlaması açısından değinilmiştir.

Araştırma sonuçlarına bakıldığında 31 Mart 2019 Yerel Seçimleri'ne yönelik en fazla haberin Sözcü gazetesinde (yüzde 41,1) yayınlandığı, bu sırayı Sabah ve Hürriyet gazetelerinin takip ettiği görülmektedir. Seçim sürecine yönelik haberlerin büyük oranda (yüzde 81) gazete sayfasının muhtelif yerlerinde yayınlandığ1 tespit edilmiştir. Bu durum Türkiye'nin geleceğini etkileyen siyasi seçimlerle ilgili gazetelerin beklenen kadar ilgi göstermemiş oldukları düşüncesini oluşturmaktadır.

Gazetede yer alan seçim haberlerine konu olan partilere bakıldığında; daha çok AK Parti ve CHP'nin yer aldığı görülmüştür. Bu duruma yönelik hem gazetelerin ideolojik bakış açılanı hem de dönemin siyasi yapısı ve düşünce iklimi bakımından bu partilerin iki farklı tarafı temsil etmelerinin etkili olduğu yorumu yapılabilir.

Seçim döneminin ruhuna uygun olarak içeriğinde en fazla yerel seçim ve adayların işlendiği gazete haberlerinde siyasi aktör olarak büyük oranda (yüzde 61,2) parti genel başkanına, daha sonra belediye başkan adayına (yüzde 28,7) yer verilmiştir. Seçim haberlerine konu olan siyasi aktör değişkeninde ve haber görselinde daha çok parti genel başkanına daha sonra belediye başkan adayına yer verilmesi gazetelerin bu seçimleri bir yerel seçim olmaktan çıarılıp genel seçim havasında değerlendirdiği yorumunu içerebilir.

Seçim haberlerinde gazetelerin partiye yaklaşımlan büyük oranda nötr olsa da haberlerin anlatım tarzının ve üslubunun daha çok eleștirel suçlayıcı nitelikte olduğu ve haberde büyük oranda (yüzde 73,6) yorum yapıldığı bulgulanmıştır. Bu sonuçlar da haberde objektiflik kriterinin göz ardı edildiğini ortaya koymaktadır.

Sabah, Hürriyet ve Sözcü gazetesinde 31 Mart 2019 Yerel Seçimleri’ne yönelik toplamda 258 haber yayınlamışardır. Bu haberlerin çoğunluğunda (yüzde 79,1) gazetelerin partilere nötr yaklaştıkları görülmüştür. Gazeteler özelinde bakıldığında ise Sabah gazetesinde yayınlanan 78 haberin çoğunda nötr olarak davranılsa da AK Parti'ye ilişkin haberlerinin bir kısmında olumlu, CHP haberlerinin ise büyük çoğunluğunda (yüzde 85) olumsuz yaklaşım sergilediği görülmüştür. Hürriyet gazetesinde yayınlanan toplam 74 haberin ise neredeyse tamamında nötr yaklaşımın benimsendiği görülmüştür. Sözcü gazetesinde yayınlanan toplam 106 haberin çoğunluğunda nötr yaklaşım sergilenirken, AK Parti haberlerinin bir 
kısmında (yüzde 29,7) olumsuz yaklaşıldığı, CHP haberlerinin ise belli oranda (yüzde 17,5) olumlu yaklaşıldığ1 görülmüştür.

Gazete haberlerinde yorum durumuna bakıldığında ise, Sabah gazetesinde yayınlanan AK Parti ve CHP haberlerinde yorum yapıldı̆̆ı bulgulanmıştır. Hürriyet gazetesinde yayınlanan haberlerin ise neredeyse tamamında yoruma yer verilmezken, Sözcü gazetesinde yer alan haberlerin ise belli oranda haberlerde yoruma yer verildiği görülmüştür.

Gazetelerde yer alan haberlerin gazete sayfasındaki konumu incelendiğinde ise Sabah gazetesinde yer alan AK Parti ve CHP haberlerinin çoğunluğu gazete sayfasının muhtelif yerlerinde yayınlanırken, her iki partinin de belli oranda haberleri manşetten yayınlanmıştır. Hürriyet gazetesinde ise yalnızca AK Parti haberlerinin yüzde 18,2'sinin manşetten diğerleri ilk sayfasının muhtelif yerlerinde verilmiştir. Sözcü gazetesinde de haberlerin çoğu gazetenin ilk sayfasının muhtelif yerlerinde verilirken diğerlerinden farklı olarak AK Parti (yüzde 5,4) ve CHP (yüzde 12,5) haberlerinin bir kısmı sürmanşet gibi gazetenin en önemli yerinde yayınlandığı tespit edilmiştir.

Basın kuruluşlarının objektif yayıncılık anlayışı içinde yayınlar yapmaları demokrasinin işleyişi, gelişmesi ve toplum çıkarlarının sağlanması açısından önemli bir gerekliliktir (Taşdemir vd. 2003, s. 32). Bu bilgi bağlamında objektiflik unsurunun dikkate alınarak yapılan bu çalışmaya göre, Hürriyet gazetesinin incelenen haberlerinde partilere yönelik aynı oranda yaklaştığı görülmüştür. Diğer iki gazeteye oranla Hürriyet gazetesi haberlerinde partilere daha objektif bir tutum sergilediği bulgulanmıştır. Ancak Sabah ve Sözcü gazetelerinde belli partileri ön plana çıkarmayı ve diğerlerini göz ardı ettikleri tespit edilmiştir. Bunun yanında her iki gazetede yapılan bazı haberlerde yoruma başvurulduğu görülmüştür. Bu durum Sabah ve Sözcü gazetelerinin objektiflik ilkesine uymadıkları sonucunu ortaya çıarmıştır. Bir diğer ifade ile 31 Mart 2019 Yerel Seçimleri öncesi Sabah ve Sözcü gazetelerinin partilere ilişkin yapmış oldukları haberlerde objektif habercilik anlayışında denge unsurunu göz ardı ettikleri görülmüştür.

Sonuç olarak, bu çalışma 31 Mart 2019 Yerel Seçimleri'nde Türk yazılı basının seçime katılan partilere ilişkin seçim haberlerinde yaklaşımlarını çözümleme üzerine dizayn edilmiştir. Çalışmada elde edilen bulgularla Hürriyet gazetesinin partilere ilişkin haberlerde objektif bir tutum sergilemeye çalıştı̆̆ını ancak Sabah ve Sözcü gazetesinin partilere ilişkin objektif bir tutum sergilemediğini ortaya çıkarmıştır. $\mathrm{Bu}$ çalışmanın, ileride benzer konuda, farklı kitle iletişim araçlarında yer alan haberlerin analizlerinin yapılmasında literatüre önemli bir katkı sağlayacağı düşünülmektedir.

\section{Extended Abstract}

In this study, which discussed discussions about objectivity in news and news, the sources contained in the literature on news and objectivity were scanned and transfers were made by referring to the sources referred to as the main ones on this issue. $\mathrm{n}$ addition to the theoretical information contained in the literature on the subject, previous studies on this subject and the results of these studies are included.

Compared to the literature contained in the content in the mass media, especially News carrying the news value of the information that should be an emphasis on the objectivity of objectivity of the criteria is the most important element is arguing that. In the light of this information, problem of the study ; The newspapers for the 31 March 2019 Local Elections did not comply with the element of objectivity in political news.

On the basis of this problem, the research question of the study is "Did the newspapers comply with the principles of objectivity in their news about political parties before the March 31, 2019 Local Elections?" The purpose of this study 31 March 2019 local elections in the course of the written press in the elections, AK Party, MHP, CHP, IYI Party, HDP, Saadet Party and the parties of the Republic of Alliance (AK Party and MHP) and the National Alliance (CHP, IYI Party), in the news for how, to what extent and how often approach in this approach is to reveal whether objectivity metrics are being met.

Content analysis method was used in this study, which examined the approach of newspapers to the parties participating in the 31 March 2019 local elections. Content analysis method is a quantitative, systematic and objective method used in media content (Wimmer ve Dominick, 2007: 19: 21). Descriptive coding and prepared by looking at those expressed in media texts with a ruler, how often stated or written in the media content analysis method was chosen as the most appropriate method because it allows you to 
expose content. Content analysis coding ruler was used as a data collection technique in the research. There are 13 classification systems in the coding ruler.

The sample of this work, which is composed of political parties in Turkey and the Turkish written press, is composed of the newspapers Hurriyet, Sabah and Sözcü. In the selection of these newspapers as examples, the publication policies and ideologies of the newspapers were taken into account.

The study is limited to the first pages of newspapers with the news of the parties ' elections and the continuation of these news to cover the period one month before the election, i.e. between 3 March 2019 and 30 March 2019. The reason why the first pages of newspapers are selected for analysis is because the first pages of newspapers constitute the most important page.

Looking at the results of the research, it is seen that the most news about the March 31, 2019 local elections was published in the newspaper Sözcü (\% 41.1), followed by Sabah and Hurriyet newspapers. It was found that news about the election process was published in various parts of the newspaper page ( $\%$ 81). Looking at the parties that are the subject of Election News in the newspaper, it was seen that the AK Party and the CHP were more involved. In keeping with the spirit of the election period, the most local elections and candidates were covered in newspaper reports, with a large proportion (\% 61.2) as political actors, followed by a candidate for mayor ( $\% 28.7)$.

Although their approach to the party was largely neutral in Election News, the style and style of the news was found to be more critical and incriminating, with mostly (\% 73.6) commenting on the news.

Looking at their approach to the parties in the news in the newspapers, although most of the 78 News published in the Sabah newspaper were treated as neutral, some of their news about the AK Party was positive, and the vast majority of CHP news (\% 85) showed a negative approach. A total of 74 reports published in Hürriyet newspaper showed that a neutral approach was adopted in almost all of them. While the majority of the 106 News published in the newspaper Sözcü showed a neutral approach, some of the AK Party news (\% 29.7) was approached negatively, and CHP news was approached positively in a certain proportion $(\% 17.5)$.

Looking at the status of comments in newspaper news, it was found that comments were made in AK Party and CHP news published in Sabah newspaper. Almost all of the news published in the Hurriyet newspaper is not included in the comment, while the news contained in the Sözcü newspaper is included in the comment in a certain proportion of the news.

Keywords: News, Objectivity, Content Analysis, Newspapers, Elections

\section{Kaynakça}

Akkaya, N. O. (2019). Yaz̨l Basinda Tarafsızhk İlkesi ve 2017 Referandumu, Marmara Üniversitesi Sosyal Bilimler Enstitüsü, Yayımlanmamış Yüksek Lisans Tezi, İstanbul.

Arsan, E. ve Çoban, S. (2014), Medya ve İktidar - Hegemonya, Statüko, Direnis, İstanbul: Doğa Basin Yayin.

Aslan, A. (2019). ). 31 Mart 2019 Yerel Seçimleri'nde Cumbur Itttifaki'nnn Siyasal İletişim Stratejisi, Siyaset, Ekonomi ve Toplum Araştırmaları Vakfi (SETA), Mart 2019, Sayı:274.

Aslan, K. (2003). Haberim Var! Örneklerle Haberin ABC'si, İstanbul: Anahtar Kitaplar Yayınevi.

Bekiroğlu, O. ve Balc1, Ş. (2019). 31 Mart 2019 Yerel Seçimleri'nde Millet İttifakinnn Siyasal İletişim Stratejisi, Siyaset, Ekonomi ve Toplum Araştırmaları Vakfı (SETA), Mart 2019, Sayı:273,

Bennett, W. L. (2000). Politik Illlïsyon ve Medya. Seyfi Say (Çev.), İstanbul: Nehir Yayınları.

Çağlar, İ., Erol, M. \& Akdemir, K. H. (2018). 24 Haziran 2018 Cumburbaşkan Seçiminin Siyasal İletisimi, Siyaset, Ekonomi ve Toplum Araştırmaları Vakfi (SETA).

Devran, Y. ve Özcan, Ö. F. (2016). 15 Temmuz Darbe Girişimi: Geleneleselden Yeniye Medya Araclarmnn Kullanum, AJIT-e: Online Academic Journal of İnformation Technology, 7, (25), s. 71-91, Retrieved from https://dergipark.org.tr/tr/pub/ajite/issue/54429/740860.

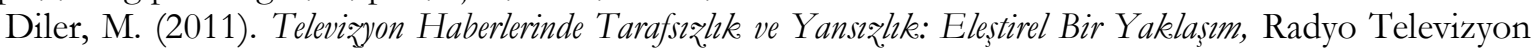
Üst Kurulu Uzmanlık Tezi, Ankara.

Duran, H. (2017). Meral Akssenerin Siyasi Anlamı ve IYI Parti, Siyaset, Ekonomi ve Toplum Araştırmaları Vakfi (SETA), Ekim 2017, Sayı:223.

Erdoğan, İ. ve Alemdar, K. (1990). İletisim ve Toplum, Ankara: Bilgi Yayınevi. 
Girgin, A. (2000), Haber, İstanbul Üniversitesi İletişim Fakültesi Dergisi, Say1: 10, Sayfa: 85- 96, İstanbul. Girgin, A. (2003). Yaz̨l Basinda Haber ve Habercilik Etiği, 2. Bask1, İstanbul: İnk1lap Kitapevi.

Hackett, A. R. (2000). "Bir Paradigmann Önemini Yitiriși Haber Medyası Callsmalarnnda Yanlllıe ve Nesnellik”, Çev. Ayşe İnal, Ankara: A.Ü İletişim Fakültesi Yıllık (1997-1998), 31-72.

Harrison, J. (2000). Terrestrial TV News in Britain The Culture of Production, Mancshester University Press. İnal, A. (1996). Haberi Okumak, İstanbul: Temuçin Yayınları.

İrvan, S. (2004). Gazetecilik Etiği, Nilgün Gürkan Pazarcı (Ed.), Türkiye'de Kittle İletisimi, Ankara: Turhan Kitapevi.

Kilıç, S. (2011). Antalya'daki Yerel Gazetelerin Siyasal Yanllık Açısndan İncelenmesi, Gümüşhane Üniversitesi İletişim Fakültesi Dergisi, Sayı 2, Eylül, 70-95.

Köker, İ. (2016). Türkiye'de 2016 yal nasıl geçti? - BBC News Türkçe, https://www.bbc.com/turkce/haberler-turkiye-38469301 (Erişim: 14 Ocak 2021)

McNair, B. (2005). “What is Journalism?” Hugo de Burgh (Ed.), Making Journalist, Roudledge: 25-43.

Miş N. ve Eren, A. (2014). Siyasal Partilerin Yerel Viżyonu. İstanbul Seçimleri, Say1:91, Siyaset, Ekonomi ve Toplum Araştırmaları Vakfi (SETA).

Miş, N. ve Duran, H. (2018). 24 Hažiran Seçim Somuclar Analiæ̧, Siyaset, Ekonomi ve Toplum Araştırmaları Vakfi (SETA), Temmuz 2018, Sayı:250.

Miş, N. ve Duran, H. (2019). Itttifaktan Blok Siyasetine 31 Mart Yerel Seçimleri, Adam Akademi, 9/2, 363 393.

Olkun, E. O. (2015). "Cumhurbaşkanlığı Seçiminde Türk Yazılı Basınının Adaylara Yaklaşımı: Milliyet, Sabah ve Zaman Gazeteleri Örneği”, Faruk Temel ve Onur Önürmen (Eds.), Cumburbaşkanhlğ̆ Seçimi ve Medya, Ankara: Nobel Kitap.

Olkun, E. O. (2017). Haber ve Güven, Konya: Literatürk.

Özer, Ö. (2010). Liberal Basin, Konya: Literatürk.

Özer, Ö. (2012). Haberde Objektiflik Sorunu: Cumhuruyet, Hürriyet ve Zaman Gazetelerinde Yapılan

Çözümleme, Ömer Özer (Ed.), Haberin Doğası Gazetecilikte İdealler ve Sorunlar, Konya: Literatürk Yayınları.

Şeker, T. B. (2004). Türk Basinnda Objektiflik. Fazilet Partisinin Kapatılması Örmeği, Selçuk İletişim, 3(3), 35-47.

Taşdemir, E., Akdağ, M., Balcı, Ş. (2003). 3 Kasım 2002 Genel Seçimleri’nde Yažlh Basmmn Siyasi Partilere Yaklaşımı (AKP ve CHP Ömeğı). Selçuk İletişim Dergisi, 3(1), 20-30.

Tokgöz, O. (2017). Temel Gazetecilik, 12. Bask1, Ankara: İmge Kitapevi.

Yüksel, E. (2010). Medya ve Habercilike, Konya: Çizgi Kitapevi.

Zeytin Dalı Harekatı Nedir? Amacı ne? Kimlere karșı yapılıyor?, Zeytin Dalı Harekatı nedir? Amacı ne? Kimlere karşı yapıllyor? (internethaber.com), (Erişim: 15 Ocak 2021.) 